\title{
A NEW INDEX OF GLOBALIZATION: MEASURING IMPACTS OF INTEGRATION ON ECONOMIC GROWTH AND INCOME INEQUALITY
}

Hyeon-Seung Huh and Cyn-Young Park

NO. 587

July 2019
ADB ECONOMICS WORKING PAPER SERIES 


\section{A New Index of Globalization: Measuring Impacts of Integration on Economic Growth and Income Inequality}

Hyeon-Seung Huh and Cyn-Young Park

No. 587 | July 2019
Hyeon-Seung Huh (hshuh@yonsei.ac.kr) is professor at Yonsei University in Seoul, Republic of Korea. Cyn-Young Park (cypark@adb.org) is director of the Regional Cooperation and Integration Division in the Economic Research and Regional Cooperation Department of the Asian Development Bank.

The authors are grateful to Mara Claire Tayag, Racquel Claveria, Paul Mariano, and Jisu Lee for their devoted and tireless efforts in collecting and compiling the data. 
(C) 2019 Asian Development Bank 6 ADB Avenue, Mandaluyong City, 1550 Metro Manila, Philippines

Tel +632632 4444; Fax +6326362444

www.adb.org

Some rights reserved. Published in 2019.

ISSN 2313-6537 (print), 2313-6545 (electronic)

Publication Stock No. WPS190245-2

DOI: http://dx.doi.org/10.22617/WPS190245-2

The views expressed in this publication are those of the authors and do not necessarily reflect the views and policies of the Asian Development Bank (ADB) or its Board of Governors or the governments they represent.

ADB does not guarantee the accuracy of the data included in this publication and accepts no responsibility for any consequence of their use. The mention of specific companies or products of manufacturers does not imply that they are endorsed or recommended by ADB in preference to others of a similar nature that are not mentioned.

By making any designation of or reference to a particular territory or geographic area, or by using the term "country" in this document, $A D B$ does not intend to make any judgments as to the legal or other status of any territory or area.

This work is available under the Creative Commons Attribution 3.0 IGO license (CC BY 3.0 IGO)

https://creativecommons.org/licenses/by/3.o/igo/. By using the content of this publication, you agree to be bound by the terms of this license. For attribution, translations, adaptations, and permissions, please read the provisions and terms of use at https://www.adb.org/terms-use\#openaccess.

This CC license does not apply to non-ADB copyright materials in this publication. If the material is attributed to another source, please contact the copyright owner or publisher of that source for permission to reproduce it. $\mathrm{ADB}$ cannot be held liable for any claims that arise as a result of your use of the material.

Please contact pubsmarketing@adb.org if you have questions or comments with respect to content, or if you wish to obtain copyright permission for your intended use that does not fall within these terms, or for permission to use the ADB logo.

Corrigenda to ADB publications may be found at http://www.adb.org/publications/corrigenda.

Note:

In this publication, “\$” refers to United States dollars.

The ADB Economics Working Paper Series presents data, information, and/or findings from ongoing research and studies to encourage exchange of ideas and to elicit comment and feedback about development issues in Asia and the Pacific. Since papers in this series are intended for quick and easy dissemination, the content may or may not be fully edited and may later be modified for final publication. 


\section{CONTENTS}

TABLES AND FIGURES

ABSTRACT V v

$\begin{array}{ll}\text { I. INTRODUCTION } & 1\end{array}$

II. LITERATURE REVIEW 3

III. CONSTRUCTION OF THE GLOBALIZATION INDEXES 5

A. Index Composition 5

B. Normalization Method 6

C. Aggregation Scheme $\quad 7$

$\begin{array}{lr}\text { IV. } & 9\end{array}$

V. A NEW INDEX OF GLOBALIZATION

VI. IMPLICATIONS FOR ECONOMIC GROWTH AND INCOME INEQUALITY 26

VII. CONCLUSIONS

APPENDIXES

Appendix 1: Data Description $\quad 35$

Appendix 2: List of Economies $\quad 36$

Appendix 3: Treatment of Missing Data 37

$\begin{array}{ll}\text { REFERENCES } & 39\end{array}$ 


\section{TABLES AND FIGURES}

\section{TABLES}

$1 \quad$ Intraregional (Extraregional) Economic Integration Index: Dimensions and Indicators 5

2 Principal Component Analysis and Weights for the Aggregation-Intraregional 10 Economic Integration Index

3 Principal Component Analysis and Weights for the Aggregation-Extraregional 11

Economic Integration Index

$4 \quad$ The Globalization Index Rankings, 2006 and 2014

$5 \quad$ Regression Results for Globalization and Economic Growth 28

6 Regression Results for Globalization and Income Inequality 30

\section{FIGURES}

$1 \quad$ Intraregional, Extraregional, and Global Economic Integration Indexes, 2006-2014 18

2 Intraregional, Extraregional, and Global Economic Integration Indexes by Income Level 19

3 Intraregional, Extraregional, and Global Economic Integration Indexes by Region 20

$4 \quad$ Dimensions of the Intraregional Economic Integration Index by Income Level 22

5 Dimensions of the Extraregional Economic Integration Index by Income Level 23

6 Dimensions of the Intraregional Economic Integration Index by Region 24

7 Dimensions of the Extraregional Economic Integration by Region 25 


\begin{abstract}
The purpose of this study is twofold. The first is to develop a new composite index of globalization based on data on 158 economies over the period 2006-2014. The second intention is to use the new index to evaluate empirically the possible effects of globalization on economic growth and income inequality. The index comprises 25 indicators that represent the key socioeconomic components of global integration. Principal component analysis is used to weight each component and construct an aggregate measure. Unlike previous composite indexes, this study separates the contributions of intraregional and extraregional integration in the construction of the globalization index. The results show that although globalization promotes economic growth, it may worsen income inequality. Highincome countries benefit most in that the positive effect of globalization on economic growth is strongest among them than on other income groups, and they experience a less pronounced widening of income inequality. Between the two drivers of global economic integration, intraregional integration is far more important than extraregional integration. The analysis also finds extraregional integration to be mainly responsible for the rise in income inequality that has accompanied globalization.
\end{abstract}

Keywords: composite index, economic globalization, economic growth, extraregional integration, income inequality, intraregional integration

JEL codes: F10, F40, I30, O10, O50 


\section{INTRODUCTION}

The rise and fall of globalization has been spectacular. ${ }^{1}$ The phenomenon has swept around the world since the 1980s under the consensus that the free movement of goods, services, capital, technology, and labor among countries integrates individual markets and economies for greater efficiency of resource allocation, higher productivity, and more investment opportunities. However, even as globalization has brought economic prosperity for the developing world, it has come under fire for its negative side effects. Some gain from trade openness while others lose. Fierce competition may have contributed to economic and social inequalities among individuals or countries, generating income and political polarization, and potentially undermining social and cultural cohesion. Eventually, it was seen as a risk to economic growth and stability. The economic subordination of underdeveloped countries, the marginalization of socioeconomically vulnerable groups, and the loss of sociocultural diversity are fiercely debated as related concerns.

Indeed, debate over the distributional effects of globalization has intensified in recent years. Some argue globalization has been a major driving force in widening inequality between and within countries (Bourguignon 2016, Milanovic 2016). Recognition that globalization comes with grave risks has garnered political support for a new form of regionalism ${ }^{2}$-a departure from regionalism based on rather exclusive, protectionist trading blocs - as a strategy to build economic and financial resilience.

Under open regionalism, regional economic integration is regarded as a building block of global economic integration. Indeed, regional integration has gathered pace, expanding in parallel with globalization itself. The trend goes back more than 2 decades. For example, Sampson and Woolcock (2003) observed that in 1 decade, the world had seen the most ambitious round of multilateral trade negotiations successfully concluded, while at the same time, regional trading arrangements proliferated. Further, growing attention has been paid to how the expansion of regionalism is related to the context of globalization (Söderbaum and Shaw 2003, Woolcock 2006).

However, there appears to have never been an attempt to quantitatively assess the extent to which regional economic integration and global economic integration are related to each other: for example, the contribution of regional integration to global integration, interactions between these two processes, and ultimately their separate and synergetic impacts on economic growth and income inequality. The distinction between the regional and nonregional forces that propel global economic integration is particularly important when seeking to balance the slowing pace of globalization with integration policies that prioritize certain regions based on the common economic, security, or political interests and tackle weaknesses created by full economic integration at the global level.

Foreign Affairs provides a good chronicle of how globalization has risen and fallen over the past several decades (https://www.foreignaffairs.com/anthologies/globalization). For example, see Globalization and Its Discontents: Navigating the Dangers of a Tangled World by Richard N. Haass and Robert Litan (1998); Spreading the Wealth by David Dollar and Aart Kraay (2002); The Miracles of Globalization by Arvind Panagariya (2004); and Why Globalization Stalled and How to Restart It by Fred Hu and Michael Spence (2017).

2 In the mid-1980s and early 1990s, regionalism was transformed by reconfigured regional institutions such as the Association of Southeast Asian Nations, the emergence of the Asia-Pacific Economic Cooperation forum, and the European Union (EU). Such new forms of regionalism gained ground through dealing with regional financial turmoil and global economic crisis. Their actions led to the argument of a new regionalism being distinct from the old form of regionalism, which had largely been drawn from protectionist postwar interests. Indeed, some see these new regionalism (open regionalism) as a building block of global economic integration. 
Economic integration can take many forms, such as promoting trade and investment, developing infrastructure, improving people's mobility, strengthening the provision of global public goods, and providing the legal and institutional basis for international policy cooperation. Recent studies have introduced composite measures of globalization that can accommodate various aspects of economic integration. Among them, the most widely used is the KOF Index of Globalization, introduced by Dreher (2006), which measures the economic, social, and political dimensions of globalization. The KOF Index of Globalization 2017 is based on 23 variables and covers 187 countries from 1970 to 2014.

This paper develops a new global economic integration index (GEII) based on 25 variables for 158 economies over the period 2006-2014. ${ }^{3}$ The key difference from existing composite measures of globalization is that the GEII can be decomposed into regional and nonregional integration. Specifically, two subindexes are first constructed: an intraregional economic integration index (IEII) and an extraregional economic integration index (EEII). The IEII compares a country's economic activities with that of other countries in the same regional grouping, while the EEII compares that with countries outside the regional grouping. The weighted average of IEII and EEII is then computed to ascertain the GEII. As such, the GEll can assess the relative contributions of intraregional and extraregional integration to globalization. This can be useful for assessing the role of regional integration in relation to globalization and informing national and international policy decisions about how best to manage economic integration at different layers of geographic groupings, given its potential risks and weaknesses.

The second part of this paper examines empirically the possible effects of globalization on economic growth and income inequality using the index. Many studies have tackled the issue of economic integration, growth, and income inequality in parallel with globalization (Aghion and Williamson [1998] and the World Bank [2002] give detailed reviews). However, empirical testing of the dynamics between economic integration, growth, and income inequality has been a challenge. First is the measure of economic integration. Economic integration is a multifaceted process, but earlier studies used proxy variables capturing a narrow scope of economic integration. As this was often focused on trade and investment flows, it created a severe bias in the estimates. Second, socioeconomic variables associated with global economic integration may be strongly correlated with one another, leading to collinearity problems if each are included in the same regression. To tackle these deficiencies, Dreher, Gaston, and Martens (2008) suggest using a composite index that aggregates the multidimensional aspects of globalization into a single measure. The suggestion is followed in this paper.

The rest of this paper is structured as follows. Section II reviews economic literature on the openness-growth-inequality nexus and the evolution of index approach to empirically test the relationship. Section III discusses the process of constructing the composite indexes and the statistical results are reported in section IV. Section V presents the composite indexes of the GEII, IEII, and EEII and discusses their performance and features. Section VI empirically examines the possible effects of globalization on economic growth and income inequality. Section VII concludes.

3 Globalization is more than a purely economic phenomenon. However, no consensus has been reached concerning which noneconomic features need to be included in the measurement of globalization. As Dreher et al. (2010) note, the environmental impact of globalization is a good example of the debate. Further, many noneconomic features are difficult to quantify or lack proxies for numerical analysis. In view of this, the proposed index attempts to capture multidimensional aspects of global integration covering both economic and noneconomic activities. 


\section{LITERATURE REVIEW}

A substantial amount of theoretical and empirical literature has investigated the role of economic openness and globalization in advancing developmental goals. Economic integration is expected to promote growth through scale economies in common markets and production networks, free trade and investment flows, technology diffusion, and knowledge spillovers. Endogenous growth models show that integration has positive effects on both output level and growth (Grossman and Helpman 1991, Rivera-Batiz and Romer 1991, Walz 1998, Baldwin 1989). While quite a few studies also showed a positive relationship between trade openness and economic growth (Dollar 1992, 2005; Dollar and Kraay 2004; Edwards 1992, 1993; Frankel and Romer 1999; Harrison 1996; Harrison and Hanson 1999; Sachs and Warner 1995), their results were often subject to serious econometric (often endogeneity or missing variables) issues and data problems. Moreover, the extent to which increased income brought about by economic integration reduces poverty seems to have varied across and within countries.

An increasing number of studies have investigated the effect of globalization on income inequality in recent years. Dollar and Kraay (2004) argued that globalization leads to faster growth and poverty reduction in poor countries based on individual cases and cross-country analysis. Potrafke (2014) found that globalization has boosted national incomes and helped improve gender equality and human rights, but it has nonetheless increased within-country income inequality. Gozgor and Ranjan (2017) also presented evidence to show that globalization has increased both inequality and redistribution. After reviewing the related studies, Ravallion (2018) suggested that multiple factors, including trade, capital, and labor mobility, work in often subtle and ambiguous ways to influence inequality.

Global economic integration is a dynamic process where national economies interact and integrate through trade, investment, capital flow, labor migration, and technology transfers. Empirically, employing a small number of proxies based on a narrow scope of openness focusing on trade and capital flows would bias estimates of true openness effects. Harrison (1996) employed seven different measures of openness using proxies for trade and exchange rate policies and showed a positive relationship between openness and growth. Sachs and Warner (1995) also constructed a composite index to measure openness based on trade reforms. Aware of the shortcoming of these earlier openness indexes, which failed to capture the complex and multidimensional nature of globalization, recent studies attempted to construct new composite indexes based on a large number of socioeconomic variables.

The Globalization Index of A.T.Kearney/Foreign Policy (2002) was probably the first attempt to construct a composite measure of globalization. Covering 62 countries, it categorizes 14 indicators into the four dimensions of economic integration, personal contact, technology, and political engagement. Several other composite measures followed, including the G-Index (Randolph 2001), CSGR Globalization Index (Lockwood and Redoano 2005), Maastricht Globalization Index (Martens and Zywietz 2006), and KOF Index of Globalization (Dreher, Gaston, and Martens 2008). While these indexes differ in the number of countries analyzed, years covered, indicators, and weighting schemes utilized, each of them combines data on a country-by-country basis into one aggregate to measure globalization.

One of the common findings from these globalization indexes is that most top rankers are European countries. In the Maastricht Globalization Index, for example, the top 10 most globalized countries are in Europe. The question is then about whether the integration results are the 
consequences of regionalization or globalization. Dreher et al. (2010), Martens et al. (2015), and Vujakovic (2009) point out that this is an important criticism of many composite indexes that cannot distinguish globalization from concepts such as openness and regionalization. Taking trade as an example, Vujakovic (2009) claims that trade with neighboring countries and trade with countries outside the region cannot be treated equally because the former depicts regionalization, while the latter is an indication of globalization.

Some studies constructed measures of regional integration, typically employing proxies or dummies such as membership in regional trade agreements, intraregional trade shares, or average tariffs based on most-favored-nation status. For instance, DiCaprio, Santos-Paulino, and Soklova (2017) constructed indexes for internal and external exposure to specific regional groupings based on membership of regional trade agreements to test the link between regional integration and withincountry inequality in member countries. Similarly, Beckfield (2006) utilized intraregional trade share as a measure for regional economic integration in Europe and found a significant positive link between regional economic integration and inequality. Bo and Woo (2008) developed composite indexes of economic integration in Asia and the Pacific region by applying weights generated by panel principal component analysis (PCA) using distance to reference or base year and the conversion of raw indicators to percent share over total. PCA is a well-known statistical technique to reduce the dimensionality of data adopted to combine sets of variables into a single variable. ${ }^{4}$ It receives detailed treatment in Jackson (1991), Johnson and Wichern (2007), Jolliffe (2002), and Srivastava (2002).

Huh and Park (2018) and Park and Claveria (2018a) applied a two-stage PCA analysis to generate regional integration indexes encompassing six socioeconomic dimensions. In particular, Park and Claveria (2018b) show a positive relationship between regional integration and growth and poverty reduction by using the indexes.

While there have been separate attempts to measure economic integration at the global and regional levels, no studies so far have investigated how regionalization relates to globalization. As previous studies pointed out, some regions have spearheaded regionalization for economic openness, as a building block for globalization and a more controlled path toward economic liberalization. Some also argue regionalization may mitigate the risks of full liberalization, especially on financial markets and capital flows, which may invite financial contagion and risk widening cross-country and withincountry inequality, particularly for smaller countries and more vulnerable communities in the countries. However, proponents of globalization have advised avoiding preferential treatments at a regional level. While few studies tried to empirically estimate the impact of regional versus global integration on growth and related social outcomes, a number of studies note the regional variation in economic integration and its impact on growth. Darku and Yeboah (2018) investigated regional differences in economic integration, which seem to influence the impact of economic openness on per capita income growth.

4 Gwartney and Lawson (2001) state that PCA is particularly appropriate when the components measure different aspects of a composite index. Organisation for Economic Co-operation and Development (OECD) (2008) recommends it as a useful tool among the weighting schemes currently available, especially when each dimension has a small number of indicators (e.g., three to 10). 


\section{CONSTRUCTION OF THE GLOBALIZATION INDEXES}

\section{A. Index Composition}

The globalization, extraregional and intraregional integration indexes are all based on 25 indicators that measure various aspects of economic integration. These indicators are divided into six dimensions depending on their origin and relevance: trade and investment integration, money and finance integration, the value chain, infrastructure and connectivity, movement of people, and institutional and social integration. Table 1 reports the dimensions and indicators in each subcomponent as well as the data sources. The indicators are built from bilateral data with two exceptions (indicators IV-3 and IV-4 have only national data available). Most of the indicators in the table are self-explanatory. Only those warranting elaboration are discussed in Appendix 1.

This study covers 158 economies across five regions (Africa, Asia and the Pacific, the European Union [EU], Latin America, and North America). Appendix 2 provides a full list of the economies. It uses annual data from 2006 to 2014, which is the latest year for which all required data are available. Appendix 3 describes the treatment of the missing data.

Table 1: Intraregional (Extraregional) Economic Integration Index: Dimensions and Indicators

\begin{tabular}{|c|c|c|c|}
\hline Dimension & & Indicator & Data Source \\
\hline \multirow{5}{*}{$\begin{array}{l}\text { I. Trade and } \\
\text { investment } \\
\text { integration }\end{array}$} & $\mathrm{I}-1 \mathrm{i}(\mathrm{I}-1 \mathrm{e})$ & Proportion of intraregional (extraregional) goods exports to GDP & DOTS, WDI \\
\hline & $\mathrm{I}-2 \mathrm{i}(\mathrm{I}-2 \mathrm{e})$ & Proportion of intraregional (extraregional) goods imports to GDP & DOTS, WDI \\
\hline & $\mathrm{I}-3 \mathrm{i}(\mathrm{I}-3 \mathrm{e})$ & Intraregional (extraregional) trade intensity index & DOTS \\
\hline & $\mathrm{I}-4 \mathrm{i}(\mathrm{I}-4 \mathrm{e})$ & Proportion of intraregional (extraregional) FDI inflows to GDP & Greenfield \\
\hline & $1-5 i(1-5 e)$ & $\begin{array}{l}\text { Proportion of intraregional (extraregional) FDI inflows plus outflows } \\
\text { to GDP }\end{array}$ & $\begin{array}{l}\text { Markets, } \\
\text { M\&A FDI: } \\
\text { Zephyr }\end{array}$ \\
\hline \multirow{3}{*}{$\begin{array}{l}\text { II. Money and } \\
\text { finance } \\
\text { integration }\end{array}$} & $\mathrm{II}-1 \mathrm{i}(\mathrm{II}-1 \mathrm{e})$ & $\begin{array}{l}\text { Proportion of intraregional (extraregional) cross-border equity } \\
\text { liabilities to GDP }\end{array}$ & CPIS, WDI \\
\hline & $I I-2 \mathrm{i}(I I-2 e)$ & $\begin{array}{l}\text { Proportion of intraregional (extraregional) cross-border bond } \\
\text { liabilities to GDP }\end{array}$ & CPIS, WDI \\
\hline & II-3i (II-3e) & $\begin{array}{l}\text { Pair-wise dispersion of deposit rates averaged intraregionally } \\
\text { (extraregionally) relative to that averaged globally }\end{array}$ & $\begin{array}{l}\text { ADB using } \\
\text { various } \\
\text { sources }\end{array}$ \\
\hline \multirow[t]{4}{*}{ III. Value chain } & III-1i (III-1e) & $\begin{array}{l}\text { Ratio between the averaged trade complementarity index over } \\
\text { intraregional (extraregional) trading partners and the averaged } \\
\text { trade complementarity index over all trading partners }\end{array}$ & UNCTAD \\
\hline & III-2i (III-2e) & $\begin{array}{l}\text { Ratio between the averaged trade concentration index over } \\
\text { intraregional (extraregional) trading partners and the averaged } \\
\text { trade concentration index over all trading partners }\end{array}$ & UNCTAD \\
\hline & III-3i (III-3e) & $\begin{array}{l}\text { Proportion of intraregional (extraregional) intermediate goods } \\
\text { exports to total intraregional (extraregional) goods exports }\end{array}$ & $\begin{array}{l}\text { UN } \\
\text { Comtrade }\end{array}$ \\
\hline & III-4i (III-4e) & $\begin{array}{l}\text { Proportion of intraregional (extraregional) intermediate goods } \\
\text { imports to total intraregional (extraregional) goods imports }\end{array}$ & $\begin{array}{l}\text { UN } \\
\text { Comtrade }\end{array}$ \\
\hline
\end{tabular}




\begin{tabular}{|c|c|c|c|}
\hline Dimension & & Indicator & Data Source \\
\hline \multirow[t]{4}{*}{$\begin{array}{l}\text { IV. Infrastructure } \\
\text { and } \\
\text { connectivity }\end{array}$} & IV-1i (IV-1e) & $\begin{array}{l}\text { Ratio between the averaged trade cost over intraregional } \\
\text { (extraregional) trading partners and the averaged trade cost over all } \\
\text { trading partners }\end{array}$ & $\begin{array}{l}\text { World Bank/ } \\
\text { UNESCAP }\end{array}$ \\
\hline & IV-2i (IV-2e) & $\begin{array}{l}\text { Ratio between the averaged liner shipping connectivity index over } \\
\text { intraregional (extraregional) trading partners and the averaged liner } \\
\text { shipping connectivity index over all trading partners }\end{array}$ & UNCTAD \\
\hline & IV-3i (IV-3e) & Logistics performance index: Overall & World Bank \\
\hline & IV-4i (IV-4e) & Doing Business Index: Overall & World Bank \\
\hline \multirow[t]{4}{*}{$\begin{array}{l}\text { V. Movement } \\
\text { of people }\end{array}$} & $V-1 i(V-1 e)$ & $\begin{array}{l}\text { Proportion of intraregional (extraregional) outbound migration to } \\
\text { the population }\end{array}$ & $\begin{array}{l}\text { UN } \\
\text { Population } \\
\text { Division, WDI }\end{array}$ \\
\hline & $V-2 i(V-2 e)$ & Proportion of intraregional (extraregional) tourists to the population & WTO, WDI \\
\hline & $V-3 i(V-3 e)$ & Proportion of intraregional (extraregional) remittances to GDP & WDI \\
\hline & $V-4 i(V-4 e)$ & $\begin{array}{l}\text { Proportion of intraregional (extraregional) countries that do not } \\
\text { require an entry visa to the total number of intraregional } \\
\text { (extraregional) countries }\end{array}$ & $\begin{array}{l}\text { National } \\
\text { sources }\end{array}$ \\
\hline \multirow[t]{5}{*}{$\begin{array}{l}\text { VI. Institutional } \\
\text { and social } \\
\text { integration }\end{array}$} & VI-1i (VI-1e) & $\begin{array}{l}\text { Proportion of intraregional (extraregional) countries that have } \\
\text { signed free trade agreements to the total number of intraregional } \\
\text { (extraregional) countries }\end{array}$ & DESTA \\
\hline & $\mathrm{VI}-2 \mathrm{i}(\mathrm{VI}-2 \mathrm{e})$ & $\begin{array}{l}\text { Proportion of intraregional (extraregional) countries that have an } \\
\text { embassy to the total number of intraregional (extraregional) } \\
\text { countries }\end{array}$ & $\begin{array}{l}\text { Europa World } \\
\text { Yearbook }\end{array}$ \\
\hline & VI-3i (VI-3e) & $\begin{array}{l}\text { Proportion of intraregional (extraregional) countries that have } \\
\text { signed business investment treaties to the total number of } \\
\text { intraregional (extraregional) countries }\end{array}$ & $\begin{array}{l}\text { UNCTAD, } \\
\text { DESTA }\end{array}$ \\
\hline & $\mathrm{VI}-4 \mathrm{i}(\mathrm{VI}-4 \mathrm{e})$ & $\begin{array}{l}\text { Proportion of intraregional (extraregional) countries that have } \\
\text { signed double taxation treaties to the total number of intraregional } \\
\text { (extraregional) countries }\end{array}$ & UNCTAD \\
\hline & VI-5i (VI-5e) & $\begin{array}{l}\text { Cultural proximity with intraregional (extraregional) countries } \\
\text { relative to that with all countries }\end{array}$ & CEPII \\
\hline
\end{tabular}

ADB = Asian Development Bank, CEPII = Centre d'Études Prospectives et d'Informations Internationales, CPIS = Coordinated Portfolio Investment Survey; DESTA = Design of Trade Agreements; DOTS = Direction of Trade Statistics; FDI = Foreign Direct Investment; GDP = gross domestic product, M\&A = Mergers and Acquisitions, UNCTAD = United Nations Conference on Trade and Development, UN Comtrade $=$ United Nations International Trade Statistics Database, UNESCAP $=$ United Nations Economic and Social Commission for Asia and the Pacific, $\mathrm{WDI}=$ World Development Indicators, $\mathrm{WTO}=$ World Trade Organization .

Note: Parentheses refer to cases for the extraregional economic integration index.

Sources: fDi Markets. www.fdimarkets.com; Bureau Van Dijk. https://www.bvdinfo.com/; CEPII. www.cepii.fr.

\section{B. Normalization Method}

As indicators convey quantitatively different information, some cannot be matched with others and have different measurement units. Normalization is therefore required before aggregation to bring these indicators to the same standard. Among the various normalization methods (for a survey, see Organisation for Economic Co-operation and Development 2008), the z-score (standardization) 
scheme widely used in other composite indexes is used here. ${ }^{5}$ This procedure converts indicators into a common scale with an average of 0 and standard deviation of 1 . The average of 0 means that it avoids introducing aggregation distortions stemming from differences in the indicator means. The formula to calculate the $z$-score is the value of an indicator minus the average of the indicator across countries, divided by the standard deviation. To ensure data comparability not only for a given year, but also over time, each indicator for each year is normalized by using the average and standard deviation values for the initial year (2006). ${ }^{6}$ Therefore, the normalized indicator $x_{i j}^{t}$ is

$$
x_{i j}^{t}=\frac{I D_{i j}^{t}-I D_{i \bullet}^{2006}}{\sigma_{i \bullet}^{2006}},
$$

where $I D_{i j}^{t}$ is an original indicator $i$ for country $j$ in year $t, I D_{i \bullet}^{2006}$ is the average of indicator $i$ across countries in the initial year, and $\sigma_{i \bullet}^{2006}$ is the standard deviation of indicator $i$ across countries in the initial year. In some cases, high values of the original indicator lead to low integration: II-3i/II-3e, III$2 \mathrm{i} / \mathrm{III}-2 \mathrm{e}$, and IV-1i/IV-1e. ${ }^{7}$ For these indicators, the normalized value is multiplied by -1 to preserve the ordinal relationship, which is given as

$$
x_{i j}^{t}=-\frac{I D_{i j}^{t}-I D_{i \bullet}^{2006}}{\sigma_{i \bullet}^{2006}} .
$$

\section{Aggregation Scheme}

With indicators normalized, there are two steps to produce the IEII/EEII. First, the indicators in each dimension are weight averaged to construct a composite dimensional index and, second, the derived dimensional indexes are weight averaged, yielding an overall index of the IEII/EEII. In each step, the weights are empirically determined based on PCA. It partitions the variance in a set of variables and uses it to determine the weights that maximize the resulting principal component's variation. This captures variations in the data to the maximum extent possible. A number of other studies have employed PCA to combine sets of indicators into single composites, such as the previously mentioned KOF Index of Globalization (KOF Swiss Economic Institute), Economic Freedom of the World Index (Fraser Institute), Chicago Fed National Activity Index (Federal Reserve Bank of Chicago), and General Indicator of Science and Technology (National Institute of Science and Technology Policy).

5 Examples include the Technology Achievement Index (United Nations); Internal Market Index (DG MARKT, European Commission); Investment in the Knowledge Based Economy (DG RTD, European Commission); Performance in the Knowledge Based Economy (DG RTD, European Commission); Relative Intensity of Regional Problems in the Community (European Commission); Environmental Sustainability Index (World Economic Forum); and Composite Leading Indicators (OECD).

6 To assess country performance across years, the z-score normalization typically calculates the average and standard deviation across countries for a reference year, usually the initial point in time (OECD 2008).

7 The concentration index in III-2i (III-2e) measures the concentration of countries' exports and imports in several products. It is generally thought that if two countries produce diversified products, intraregional (extraregional) integration leads to more benefits, as the countries can complement each other in trade. Under this premise, higher concentration index values are associated with low intraregional (extraregional) integration. 
The discussion below focuses on how to generate weights for the individual components once PCA results are obtained.

Suppose a four-variable data vector $X=\left(x_{1}, x_{2}, x_{3}, x_{4}\right)^{\prime}$, which has a correlation matrix $\Sigma$ with eigenvalue-eigenvector pairs $\left(\lambda_{1}, e_{1}\right),\left(\lambda_{2}, e_{2}\right),\left(\lambda_{3}, e_{3}\right)$, and $\left(\lambda_{4}, e_{4}\right)$, where $\lambda_{1} \geq \lambda_{2} \geq \lambda_{3} \geq \lambda_{4}{ }^{8}$. The first principal component is constructed using the eigenvector corresponding to the largest eigenvalue $\lambda_{1}$. This is $Z_{1}=e_{1}^{\prime} X$ and accounts for the largest possible variation in the data with a variance of $\operatorname{Var}\left(Z_{1}\right)=\lambda_{1}$. The eigenvector corresponding to the second largest eigenvalue $\lambda_{2}$ makes up the second principal component given as $Z_{2}=e_{2}^{\prime} X$ with a variance of $\operatorname{Var}\left(Z_{2}\right)=\lambda_{2} . Z_{2}$ is orthogonal to $Z_{1}$ and explains additional but less variation than $Z_{1}$. Subsequent principal components are orthogonal to the previous components, and each captures additional but progressively smaller variations in the data. The orthogonality of the principal components implies that changes in one component do not affect other components, which can be a desirable feature for composite indexes. Since the total data variance is four (that is the number of variables) and equals the sum of the eigenvalues, the proportion of total data variance accounted for by the $j^{\text {th }}$ principal component is $\lambda_{j} / 4$.

For illustration, suppose that the first two principal components $\left(Z_{1}\right.$ and $\left.Z_{2}\right)$ are chosen to characterize the variation in $X$. The correlation coefficients between $X$ and $Z$ are called loadings, given as $\operatorname{Corr}\left(x_{i}, Z_{j}\right)=\rho_{i j}=e_{i j} \sqrt{\lambda_{j}}, i=1,2,3,4$, and $j=1,2$, where $e_{i j}$ is the $i^{\text {th }}$ element of the eigenvector $j$ (for a derivation, see Johnson and Wichern 2007, 433). The square of the loadings, $\rho_{i j}^{2}$, represents the proportion of variance in variable $x_{i}$, explained by the principal component $Z_{j}$. As $\sum_{i=1}^{4} e_{i 1}^{2}=\sum_{i=1}^{4} e_{i 2}^{2}=1$, the sums of the squared loadings on $Z_{1}$ and $Z_{2}$ are $\sum_{i=1}^{4} \rho_{i 1}^{2}=\lambda_{1}$ and $\sum_{i=1}^{4} \rho_{i 2}^{2}=\lambda_{2}$, which are the variances of $Z_{1}$ and $Z_{2}$, respectively. By using this, the squared loadings are normalized to unity sum, that is, $\bar{\rho}_{i j}^{2}=\rho_{i j}^{2} / \lambda_{j}$. Finally, $\theta_{j}=\lambda_{j} /\left(\lambda_{1}+\lambda_{2}\right), j=1,2$ is constructed to measure the proportion of explained variance in the data when considering only the first two principal components. $\theta_{1}$ and $\theta_{2}$ are the weights assigned to the respective principal components for the aggregation. Hence, the composite index is

$$
\left(\bar{\rho}_{11}^{2} * \theta_{1}+\bar{\rho}_{12}^{2} * \theta_{2}\right) x_{1}+\left(\bar{\rho}_{21}^{2} * \theta_{1}+\bar{\rho}_{22}^{2} * \theta_{2}\right) x_{2}+\left(\bar{\rho}_{31}^{2} * \theta_{1}+\bar{\rho}_{32}^{2} * \theta_{2}\right) x_{3}+\left(\bar{\rho}_{41}^{2} * \theta_{1}+\bar{\rho}_{42}^{2} * \theta_{2}\right) x_{4} \text {. }
$$

8 The covariance matrix can also be used, depending on the nature of the data employed. If variances differ widely or the units of measurement are not commensurate, the covariance matrix will be dominated by variables with large variances. In the empirical part to follow, use of the correlation matrix prevents these variables from unduly influencing the principal components. 


\section{EMPIRICAL RESULTS}

The IEII and EEII are constructed following the procedure described above. Tables 2 and 3 report the results. First, the PCA is applied to each dimension to determine the number of principal components for capturing movements in that dimension. There is no universally accepted rule as to how many principal components should be retained. Yet, Nardo et al. (2011) observe that a rule of thumb is to choose components that: (i) have associated eigenvalues exceeding 1 (Kaiser criterion), (ii) contribute individually to the explanation of total variance by at least $10 \%$, and (iii) contribute cumulatively to explain more than $60 \%$ of the total variance.

Looking at the results for the IEll (Table 2), these selection criteria suggest the first two principle components to be chosen in dimension I. The principal component corresponding to the largest eigenvalue of 2.22 explains $45 \%$ of the total variation in the indicators. The principal component for the second largest eigenvalue of 1.28 accounts for an additional $27 \%$ of the total variation. Therefore, the first two principal components together explain $72 \%$ of the total variation. The results for dimension $V$ yield the same implication for the number of principal components, picking up the first two. With respect to dimensions III and $\mathrm{VI}$, only the first principal component is suggested, as the second largest eigenvalue is less than 1. Nevertheless, the second principal component is also taken to retain a reasonable volume of the explained variation. The remaining dimensions (II and IV) pick up the first principal component only.

Based on the principal components chosen, the weights for combining the individual indicators in each dimension are calculated according to the procedure in section III, which are reported at the bottom of the table. It appears that the indicators are given quantitatively different weights across dimensions. Once the six-dimensional composite indexes are derived, they are combined to construct the IEII. As before, the first step is to apply PCA, the results of which appear in the panel titled "Overall" in Table 2. The first two principal components show eigenvalues exceeding 1. Nevertheless, it was decided to include the third principal component for the same reason of ensuring a reasonable volume of the explained variation. The three principal components explain $83 \%$ of the variation in the set of six dimensional composite indexes. The implied weights used to combine the dimensional indexes are reported at the bottom of the table. Dimension II has the highest weight (0.202) followed by dimensions VI (0.166), I (0.165), and IV (0.165). The least weight is given to dimension III (0.139).

Table 3 reports the corresponding results for the EEll. While these results appear more discernible, the number of principal components to retain remains unaltered from the IEII. Specifically, two principal components are chosen for dimensions I, III, V, and VI and one for dimension II. The exception is dimension IV, where the second-largest eigenvalue is greater than 1 (1.10), and therefore two principal components are retained in this dimension. Based on the principal components chosen, the weights are calculated (again, see the bottom of the table) and used to combine individual indicators, producing six dimensional composite indexes. Like the IEII, the panel titled "Overall" reports the results by applying PCA to these dimensional indexes derived for extraregional integration. While only the first two principal components show eigenvalues exceeding 1 , the third principal component is included along with the results of the IEII. The three principal components together explain $72 \%$ of the variation in the set of the six-dimensional composite indexes, relative to $59 \%$ for the case of two principal components. 
Table 2: Principal Component Analysis and Weights for the Aggregation-Intraregional Economic Integration Index

\begin{tabular}{|c|c|c|c|c|c|c|c|c|c|c|c|c|c|c|c|c|c|}
\hline \multirow[b]{4}{*}{ Eigenvalue } & \multicolumn{17}{|c|}{ Number of Principal Components } \\
\hline & \multicolumn{5}{|c|}{ Dimension I } & \multicolumn{4}{|c|}{ Dimension II } & \multicolumn{4}{|c|}{ Dimension III } & \multicolumn{4}{|c|}{ Dimension IV } \\
\hline & 1 & 2 & 3 & 4 & 5 & 1 & 2 & 3 & & 1 & 2 & 3 & 4 & 1 & 2 & 3 & 4 \\
\hline & 2.22 & 1.38 & 0.99 & 0.20 & 0.18 & 1.99 & 0.90 & 0.10 & & 1.77 & 0.89 & 0.86 & 0.47 & 2.74 & 0.67 & 0.34 & 0.24 \\
\hline \multirow[t]{3}{*}{ Cum Prop } & 0.45 & 0.72 & 0.92 & 0.96 & 1.00 & 0.67 & 0.97 & 1.00 & & 0.44 & 0.67 & 0.88 & 1.00 & 0.69 & 0.85 & 0.94 & 1.00 \\
\hline & \multicolumn{4}{|c|}{ Dimension $\mathrm{V}$} & \multicolumn{5}{|c|}{ Dimension VI } & \multicolumn{8}{|c|}{ Overall } \\
\hline & 1 & 2 & 3 & 4 & 1 & 2 & 3 & 4 & 5 & & 1 & 2 & 3 & 4 & 5 & 6 & \\
\hline Eigenvalue & 1.28 & 1.08 & 0.92 & 0.70 & 2.94 & 0.94 & 0.82 & 0.21 & 0.09 & & 3.02 & 1.07 & 0.84 & 0.47 & 0.35 & 0.21 & \\
\hline \multirow[t]{2}{*}{ Cum Prop } & 0.32 & 0.59 & 0.83 & 1.00 & 0.59 & 0.78 & 0.94 & 0.98 & 1.00 & & 0.51 & 0.68 & 0.83 & 0.90 & 0.96 & 1.00 & \\
\hline & \multicolumn{17}{|c|}{ Weights for composite indexes } \\
\hline Indicator & $\mathrm{I}-1 \mathrm{i}$ & $\mathrm{I}-2 \mathrm{i}$ & $\mathrm{I}-3 \mathrm{i}$ & $\mathrm{I}-4 \mathrm{i}$ & $1-5 i$ & $\mathrm{II}-1 \mathrm{i}$ & $I I-2 i$ & II-3i & & III-7i & III-2i & III-3i & III-4i & IV-1i & $I V-2 i$ & IV-3i & IV-4i \\
\hline Weight & 0.249 & 0.248 & 0.008 & 0.248 & 0.247 & 0.425 & 0.467 & 0.108 & & 0.280 & 0.266 & 0.103 & 0.351 & 0.255 & 0.218 & 0.274 & 0.253 \\
\hline Indicator & $\mathrm{V}-1 \mathrm{i}$ & $V-2 i$ & $V-3 i$ & $\mathrm{~V}-4 \mathrm{i}$ & VI-1i & VI-2i & VI-3i & VI-4i & VI-5i & & I & II & III & IV & $\mathrm{V}$ & $\mathrm{VI}$ & \\
\hline Weight & 0.125 & 0.259 & 0.345 & 0.271 & 0.083 & 0.215 & 0.231 & 0.223 & 0.248 & & 0.165 & 0.202 & 0.139 & 0.165 & 0.163 & 0.166 & \\
\hline
\end{tabular}

Notes: The "Cum Prop" row reports the cumulated fraction of total variation in the data accounted for by the principal components. Values in boldface are the principal components chosen for the aggregation.

Source: Authors' calculations. 
Table 3: Principal Component Analysis and Weights for the Aggregation-Extraregional Economic Integration Index

\begin{tabular}{|c|c|c|c|c|c|c|c|c|c|c|c|c|c|c|c|c|c|}
\hline & \multicolumn{17}{|c|}{ Number of Principal Components } \\
\hline & \multicolumn{5}{|c|}{ Dimension I } & \multicolumn{4}{|c|}{ Dimension II } & \multicolumn{4}{|c|}{ Dimension III } & \multicolumn{4}{|c|}{ Dimension IV } \\
\hline & 1 & 2 & 3 & 4 & 5 & 1 & 2 & 3 & & 1 & 2 & 3 & 4 & 1 & 2 & 3 & 4 \\
\hline Eigenvalue & 2.03 & 1.54 & 0.71 & 0.57 & 0.13 & 1.97 & 0.94 & 0.07 & & 1.68 & 1.11 & 0.65 & 0.54 & 2.18 & 1.10 & 0.47 & 0.23 \\
\hline \multirow[t]{3}{*}{ Cum Prop } & 0.41 & 0.72 & 0.86 & 0.97 & 1.00 & 0.66 & 0.98 & 1.00 & & 0.42 & 0.70 & 0.86 & 1.00 & 0.55 & 0.82 & 0.94 & 1.00 \\
\hline & \multicolumn{4}{|c|}{ Dimension V } & \multicolumn{5}{|c|}{ Dimension VI } & \multicolumn{8}{|c|}{ Overall } \\
\hline & 1 & 2 & 3 & 4 & 1 & 2 & 3 & 4 & 5 & & 1 & 2 & 3 & 4 & 5 & 6 & \\
\hline Eigenvalue & 1.66 & 0.99 & 0.92 & 0.43 & 2.78 & 0.99 & 0.76 & 0.30 & 0.17 & & 2.26 & 1.23 & 0.81 & 0.75 & 0.49 & 0.42 & \\
\hline \multirow[t]{2}{*}{ Cum Prop } & 0.42 & 0.66 & 0.89 & 1.00 & 0.56 & 0.76 & 0.91 & 0.97 & 1.00 & & 0.38 & 0.59 & 0.72 & 0.85 & 0.93 & 1.00 & \\
\hline & \multicolumn{17}{|c|}{ Weights for composite indexes } \\
\hline \multirow{4}{*}{$\begin{array}{l}\text { Indicator } \\
\text { Weight } \\
\text { Indicator } \\
\text { Weight }\end{array}$} & $\mathrm{I}-1 \mathrm{e}$ & $1-2 e$ & $1-3 e$ & $\mathrm{I}-4 \mathrm{e}$ & $1-5 e$ & II-1e & $11-2 e$ & $11-3 e$ & & III-1e & III-2e & $\mathrm{III}-3 e$ & $\mathrm{III}-4 \mathrm{e}$ & IV-1e & $\mathrm{IV}-2 \mathrm{e}$ & IV-3e & $\mathrm{IV}-4 \mathrm{e}$ \\
\hline & 0.146 & 0.167 & 0.174 & 0.256 & 0.257 & 0.473 & 0.477 & 0.050 & & 0.233 & 0.250 & 0.212 & 0.305 & 0.238 & 0.229 & 0.268 & 0.265 \\
\hline & V-1e & V-2e & V-3e & $V-4 e$ & VI-1e & $\mathrm{VI}-2 \mathrm{e}$ & VI-3e & $\mathrm{VI}-4 \mathrm{e}$ & $\mathrm{VI}-5 \mathrm{e}$ & & 1 & II & III & IV & V & VI & \\
\hline & 0.093 & 0.288 & 0.367 & 0.252 & 0.140 & 0.166 & 0.213 & 0.217 & 0.264 & & 0.198 & 0.210 & 0.143 & 0.147 & 0.141 & 0.161 & \\
\hline
\end{tabular}

Notes: "Cum Prop" row reports the cumulated fraction of total variation in the data accounted for by the principal components. Values in bodlface are the principal components chosen for the aggregation.

Source: Authors' calculations. 
As reported at the bottom of Table 3, the implied weights used to combine the dimensional indexes assign the highest weight (0.210) to dimension II, which is the same as for the IEII. Dimensions $\mathrm{I}(0.198)$ and $\mathrm{VI}(0.161)$ follow, and dimension $\mathrm{V}$ is given the least weight (0.141) in the EEII. The final task is to combine the two subcomponents of the IEII and EEII to create the GEII. For this, again PCA is applied to the sets of the IEII and EEII, which gives the eigenvalues of 1.64 and 0.39 . The first principal component corresponding to the largest eigenvalue of 1.64 accounts for $82 \%$ of the total variation. When there are only two variables, PCA always yields the same value in magnitude for the elements in the eigenvector. As such, the IEII and EEII are given an equal weight of 0.5 , and the final measure of the GEII is obtained by equally weighting its two subcomponents. ${ }^{9}$

\section{A NEW INDEX OF GLOBALIZATION}

It is important to test how the new index of globalization performs. So we compare our new measure of global economic integration with the other available composite indexes of globalization. To the best of our knowledge, only the KOF Index of Globalization (Dreher, Gaston, and Martens 2008) has been updated to include recent years (available at https://www.kof.ethz.ch/). The correlation (or Spearman rank correlation in the parenthesis, respectively) between GEII and KOF is 0.81 (0.86) over 2006 to 2014, and for each year of this period, the two have a correlation in the range of 0.79 (0.82) and $0.83(0.88)$.

For more detailed introduction of the new globalization measure for the sample countries, Table 4 reports the GEII of each economy in order of ranking. Owing to space constraints, only the results for the beginning year of 2006 (left panel) and end year of 2014 (right panel) are reported here (those for the other years are available upon request). Looking at the results for 2006 first, Luxembourg is shown to be the most globalized, with the highest score of $2.231 .^{10}$ The second highest is Canada with a score of 0.899 followed by Hong Kong, China (0.785). Singapore (0.683) and the United States (0.644) rank seventh and eighth. The other top 10 are all EU countries. The ranks from 11 th to 32 nd are also EU countries with scores ranging from 0.559 to 0.269 , except for Malaysia, ranked at 26th. The IEII and EEII for each economy are reported together in the table.

9 We have estimated a static factor model as an alternative method to combine IEII and EEII into a single index of GEII. The result is GEII_Factor $=0.2792^{*} \mathrm{IEII}+0.7208^{*} \mathrm{EEII}$, where EEII is given a higher weight instead of the equal weight as IEII. GEll_Factor exhibits a very close movement to GEll: the correlation (Spearman rank correlation) between GEII and GEll_Factor is 0.98 (0.97) over 2006 to 2014, and for each year of this period, the two have a correlation in the range of 0.97 (0.96) and 0.98 (0.98).

10 A total of 103 economies report the overall index in 2006. Other economies among the 158 in the sample were not available for the overall index, since missing data meant that some of the dimensional indexes could not be generated. The same is true for the other years, and the number of economies reporting the overall index varies through the years (with a range of 103 to 113 economies during 2006-2014). 
Table 4: The Globalization Index Rankings, 2006 and 2014

\begin{tabular}{|c|c|c|c|c|c|c|c|c|}
\hline \multirow[b]{2}{*}{ Rank } & \multicolumn{4}{|c|}{2006} & \multicolumn{4}{|c|}{2014} \\
\hline & Economy & GEII & IEII & EEII & Economy & GEII & IEII & EEII \\
\hline 1 & Luxembourg & 2.231 & 3.289 & 1.173 & Luxembourg & 2.133 & 3.049 & 1.217 \\
\hline 2 & Canada & 0.899 & 0.914 & 0.884 & Canada & 0.927 & 0.934 & 0.920 \\
\hline 3 & Hong Kong, China & 0.785 & 1.147 & 0.423 & Hong Kong, China & 0.924 & 1.202 & 0.645 \\
\hline 4 & Netherlands & 0.777 & 0.980 & 0.574 & Netherlands & 0.854 & 1.026 & 0.682 \\
\hline 5 & Ireland & 0.754 & 1.055 & 0.452 & Belgium & 0.758 & 0.912 & 0.603 \\
\hline 6 & Belgium & 0.692 & 0.884 & 0.500 & Ireland & 0.720 & 0.951 & 0.489 \\
\hline 7 & Singapore & 0.683 & 0.845 & 0.521 & United States & 0.646 & 0.738 & 0.555 \\
\hline 8 & United States & 0.644 & 0.716 & 0.572 & Germany & 0.637 & 0.826 & 0.448 \\
\hline 9 & United Kingdom & 0.619 & 0.562 & 0.676 & United Kingdom & 0.636 & 0.592 & 0.680 \\
\hline 10 & Germany & 0.615 & 0.791 & 0.438 & Singapore & 0.599 & 0.629 & 0.569 \\
\hline 11 & Sweden & 0.559 & 0.829 & 0.288 & Sweden & 0.576 & 0.807 & 0.346 \\
\hline 12 & Austria & 0.546 & 0.857 & 0.234 & France & 0.562 & 0.597 & 0.527 \\
\hline 13 & Bulgaria & 0.524 & 0.731 & 0.316 & Finland & 0.561 & 0.780 & 0.342 \\
\hline 14 & France & 0.513 & 0.542 & 0.483 & Spain & 0.559 & 0.609 & 0.508 \\
\hline 15 & Finland & 0.511 & 0.732 & 0.290 & Austria & 0.546 & 0.821 & 0.272 \\
\hline 16 & Italy & 0.490 & 0.591 & 0.390 & Czech Republic & 0.543 & 0.971 & 0.116 \\
\hline 17 & Denmark & 0.488 & 0.658 & 0.318 & Italy & 0.536 & 0.622 & 0.450 \\
\hline 18 & Spain & 0.470 & 0.558 & 0.381 & Denmark & 0.525 & 0.677 & 0.372 \\
\hline 19 & Hungary & 0.422 & 0.772 & 0.072 & Hungary & 0.517 & 0.814 & 0.219 \\
\hline 20 & Lithuania & 0.402 & 0.590 & 0.215 & Lithuania & 0.516 & 0.727 & 0.306 \\
\hline 21 & Portugal & 0.401 & 0.595 & 0.207 & Portugal & 0.491 & 0.625 & 0.358 \\
\hline 22 & Czech Republic & 0.377 & 0.761 & -0.008 & Slovak Republic & 0.477 & 0.919 & 0.035 \\
\hline 23 & Cyprus & 0.368 & 0.475 & 0.260 & Slovenia & 0.462 & 0.807 & 0.118 \\
\hline 24 & Greece & 0.367 & 0.629 & 0.106 & Bulgaria & 0.449 & 0.600 & 0.299 \\
\hline 25 & Estonia & 0.359 & 0.628 & 0.089 & Estonia & 0.442 & 0.725 & 0.159 \\
\hline 26 & Malaysia & 0.347 & 0.336 & 0.358 & Poland & 0.432 & 0.771 & 0.094 \\
\hline 27 & Slovak Republic & 0.339 & 0.714 & -0.035 & Latvia & 0.405 & 0.646 & 0.163 \\
\hline
\end{tabular}




\begin{tabular}{|c|c|c|c|c|c|c|c|c|}
\hline \multirow[b]{2}{*}{ Rank } & \multicolumn{4}{|c|}{2006} & \multicolumn{4}{|c|}{2014} \\
\hline & Economy & GEII & IEII & EEII & Economy & GEII & IEII & EEII \\
\hline 28 & Poland & 0.335 & 0.693 & -0.024 & Greece & 0.396 & 0.537 & 0.255 \\
\hline 29 & Romania & 0.328 & 0.539 & 0.118 & Cyprus & 0.393 & 0.473 & 0.313 \\
\hline 30 & Latvia & 0.309 & 0.544 & 0.073 & Romania & 0.391 & 0.615 & 0.166 \\
\hline 31 & Slovenia & 0.275 & 0.639 & -0.088 & Korea, Rep. of & 0.339 & 0.176 & 0.502 \\
\hline 32 & Malta & 0.269 & 0.407 & 0.132 & Malaysia & 0.314 & 0.278 & 0.351 \\
\hline 33 & Korea, Rep. of & 0.260 & 0.152 & 0.368 & Mauritius & 0.263 & -0.293 & 0.820 \\
\hline 34 & China, People's Rep. of & 0.124 & 0.042 & 0.205 & Malta & 0.261 & 0.410 & 0.112 \\
\hline 35 & Trinidad and Tobago & 0.123 & 0.057 & 0.188 & Belize & 0.221 & 0.041 & 0.401 \\
\hline 36 & Barbados & 0.116 & -0.177 & 0.410 & Panama & 0.166 & 0.150 & 0.183 \\
\hline 37 & Japan & 0.116 & 0.092 & 0.140 & Mexico & 0.166 & 0.058 & 0.275 \\
\hline 38 & Thailand & 0.109 & 0.195 & 0.023 & Bahamas & 0.161 & -0.141 & 0.463 \\
\hline 39 & Peru & 0.106 & 0.054 & 0.159 & China, People's Rep. of & 0.145 & 0.069 & 0.221 \\
\hline 40 & South Africa & 0.105 & -0.106 & 0.317 & Japan & 0.140 & 0.110 & 0.170 \\
\hline 41 & Bahamas & 0.103 & -0.196 & 0.403 & India & 0.132 & -0.127 & 0.390 \\
\hline 42 & India & 0.068 & -0.159 & 0.294 & Chile & 0.120 & 0.118 & 0.122 \\
\hline 43 & Australia & 0.058 & -0.003 & 0.119 & South Africa & 0.112 & -0.055 & 0.278 \\
\hline 44 & Mexico & 0.055 & -0.048 & 0.157 & St. Lucia & 0.101 & 0.064 & 0.137 \\
\hline 45 & Chile & 0.049 & 0.129 & -0.032 & Thailand & 0.079 & 0.147 & 0.011 \\
\hline 46 & Panama & 0.031 & 0.014 & 0.047 & Seychelles & 0.079 & -0.304 & 0.462 \\
\hline 47 & Viet Nam & 0.029 & 0.073 & -0.015 & Trinidad and Tobago & 0.073 & 0.033 & 0.114 \\
\hline 48 & Philippines & 0.023 & -0.007 & 0.052 & Mozambique & 0.070 & -0.171 & 0.310 \\
\hline 49 & New Zealand & 0.010 & -0.017 & 0.037 & Australia & 0.068 & -0.035 & 0.170 \\
\hline 50 & Costa Rica & -0.004 & 0.106 & -0.114 & Viet Nam & 0.066 & 0.064 & 0.067 \\
\hline 51 & Mauritius & -0.028 & -0.323 & 0.268 & Samoa & 0.065 & 0.088 & 0.042 \\
\hline 52 & Antigua and Barbuda & -0.034 & -0.146 & 0.078 & Morocco & 0.024 & -0.331 & 0.380 \\
\hline 53 & Argentina & -0.036 & -0.069 & -0.003 & New Zealand & 0.014 & 0.004 & 0.024 \\
\hline 54 & Brazil & -0.049 & -0.181 & 0.083 & Argentina & -0.013 & -0.041 & 0.015 \\
\hline 55 & Uruguay & -0.066 & -0.010 & -0.123 & Costa Rica & -0.017 & 0.129 & -0.163 \\
\hline 56 & Indonesia & -0.077 & -0.101 & -0.053 & Peru & -0.019 & -0.034 & -0.004 \\
\hline
\end{tabular}




\begin{tabular}{|c|c|c|c|c|c|c|c|c|}
\hline \multirow[b]{2}{*}{ Rank } & \multicolumn{4}{|c|}{2006} & \multicolumn{4}{|c|}{2014} \\
\hline & Economy & GEII & IEII & EEII & Economy & GEII & IEII & EEII \\
\hline 57 & Armenia & -0.085 & -0.364 & 0.194 & Georgia & -0.019 & -0.361 & 0.323 \\
\hline 58 & Madagascar & -0.090 & -0.394 & 0.214 & Brazil & -0.033 & -0.162 & 0.096 \\
\hline 59 & Guyana & -0.090 & -0.199 & 0.019 & Armenia & -0.045 & -0.309 & 0.219 \\
\hline 60 & Morocco & -0.096 & -0.364 & 0.173 & Jamaica & -0.048 & -0.088 & -0.008 \\
\hline 61 & Kyrgyz Republic & -0.096 & -0.284 & 0.092 & Barbados & -0.050 & -0.204 & 0.104 \\
\hline 62 & Georgia & -0.100 & -0.424 & 0.225 & Togo & -0.063 & -0.149 & 0.023 \\
\hline 63 & Maldives & -0.107 & 0.027 & -0.241 & Philippines & -0.064 & -0.099 & -0.029 \\
\hline 64 & Jamaica & -0.115 & -0.200 & -0.030 & Indonesia & -0.069 & -0.096 & -0.043 \\
\hline 65 & Guatemala & -0.130 & -0.009 & -0.251 & Colombia & -0.078 & -0.018 & -0.139 \\
\hline 66 & Ecuador & -0.140 & -0.037 & -0.243 & Botswana & -0.081 & -0.198 & 0.037 \\
\hline 67 & Pakistan & -0.145 & -0.303 & 0.013 & Honduras & -0.092 & -0.025 & -0.159 \\
\hline 68 & Paraguay & -0.158 & -0.002 & -0.314 & Ghana & -0.094 & -0.220 & 0.033 \\
\hline 69 & Kazakhstan & -0.158 & -0.375 & 0.058 & Brunei Darussalam & -0.097 & 0.168 & -0.362 \\
\hline 70 & Zambia & -0.163 & -0.284 & -0.041 & Zambia & -0.102 & -0.195 & -0.009 \\
\hline 71 & Cambodia & -0.168 & 0.005 & -0.342 & Dominican Republic & -0.104 & 0.004 & -0.211 \\
\hline 72 & Kenya & -0.171 & -0.290 & -0.053 & Uruguay & -0.105 & -0.073 & -0.136 \\
\hline 73 & Azerbaijan & -0.172 & -0.458 & 0.115 & Kyrgyz Republic & -0.118 & -0.343 & 0.107 \\
\hline 74 & Ghana & -0.176 & -0.244 & -0.108 & $\begin{array}{l}\text { St. Vincent and the } \\
\text { Grenadines }\end{array}$ & -0.121 & -0.042 & -0.200 \\
\hline 75 & Dominican Republic & -0.180 & -0.078 & -0.283 & Guatemala & -0.124 & -0.008 & -0.240 \\
\hline 76 & Colombia & -0.182 & -0.074 & -0.289 & Ecuador & -0.132 & -0.047 & -0.217 \\
\hline 77 & Honduras & -0.189 & -0.029 & -0.350 & Pakistan & -0.133 & -0.242 & -0.024 \\
\hline 78 & Sri Lanka & -0.192 & -0.265 & -0.119 & Nicaragua & -0.137 & -0.005 & -0.270 \\
\hline 79 & Botswana & -0.193 & -0.346 & -0.040 & Senegal & -0.138 & -0.198 & -0.078 \\
\hline 80 & Senegal & -0.194 & -0.333 & -0.054 & Paraguay & -0.139 & -0.035 & -0.242 \\
\hline 81 & Venezuela & -0.202 & -0.108 & -0.295 & Kazakhstan & -0.141 & -0.345 & 0.064 \\
\hline 82 & Nicaragua & -0.214 & -0.033 & -0.395 & Kenya & -0.146 & -0.251 & -0.041 \\
\hline 83 & Algeria & -0.219 & -0.547 & 0.109 & Tanzania & -0.150 & -0.273 & -0.027 \\
\hline 84 & Nigeria & -0.222 & -0.412 & -0.032 & Cambodia & -0.152 & -0.065 & -0.240 \\
\hline
\end{tabular}




\begin{tabular}{|c|c|c|c|c|c|c|c|c|}
\hline \multirow[b]{2}{*}{ Rank } & \multicolumn{4}{|c|}{2006} & \multicolumn{4}{|c|}{2014} \\
\hline & Economy & GEII & IEII & EEII & Economy & GEII & IEII & EEII \\
\hline 85 & Lesotho & -0.225 & -0.232 & -0.219 & Azerbaijan & -0.175 & -0.389 & 0.039 \\
\hline 86 & Tanzania & -0.234 & -0.400 & -0.067 & Nepal & -0.179 & 0.052 & -0.411 \\
\hline 87 & Sierra Leone & -0.234 & -0.480 & 0.013 & Mongolia & -0.188 & -0.134 & -0.243 \\
\hline 88 & Mozambique & -0.234 & -0.327 & -0.142 & Tajikistan & -0.198 & -0.384 & -0.013 \\
\hline 89 & Uganda & -0.252 & -0.364 & -0.141 & Venezuela & -0.203 & -0.152 & -0.254 \\
\hline 90 & Cameroon & -0.253 & -0.402 & -0.105 & Uganda & -0.211 & -0.315 & -0.106 \\
\hline 91 & Angola & -0.269 & -0.441 & -0.097 & Madagascar & -0.217 & -0.363 & -0.070 \\
\hline 92 & Bolivia & -0.275 & -0.141 & -0.408 & Sri Lanka & -0.219 & -0.344 & -0.093 \\
\hline 93 & Papua New Guinea & -0.275 & -0.142 & -0.407 & Benin & -0.221 & -0.202 & -0.240 \\
\hline 94 & Zimbabwe & -0.280 & -0.268 & -0.292 & Lao People’s Dem. Rep. & -0.233 & -0.076 & -0.390 \\
\hline 95 & Equatorial Guinea & -0.293 & -0.494 & -0.091 & Namibia & -0.234 & -0.277 & -0.190 \\
\hline 96 & Lao People's Dem. Rep. & -0.300 & -0.155 & -0.445 & Nigeria & -0.235 & -0.351 & -0.120 \\
\hline 97 & Burkina Faso & -0.310 & -0.333 & -0.286 & Congo Republic & -0.236 & -0.394 & -0.078 \\
\hline 98 & Gabon & -0.311 & -0.487 & -0.135 & Rwanda & -0.240 & -0.256 & -0.224 \\
\hline 99 & Bangladesh & -0.311 & -0.281 & -0.342 & Bolivia & -0.252 & -0.131 & -0.373 \\
\hline 100 & Malawi & -0.330 & -0.408 & -0.251 & Burkina Faso & -0.256 & -0.280 & -0.232 \\
\hline 101 & Namibia & -0.354 & -0.409 & -0.299 & Algeria & -0.270 & -0.536 & -0.003 \\
\hline 102 & Niger & -0.370 & -0.397 & -0.342 & Mali & -0.278 & -0.330 & -0.226 \\
\hline 103 & Afghanistan & -0.567 & -0.541 & -0.594 & Malawi & -0.278 & -0.390 & -0.167 \\
\hline 104 & & & & & Maldives & -0.293 & -0.198 & -0.387 \\
\hline 105 & & & & & Bangladesh & -0.295 & -0.311 & -0.279 \\
\hline 106 & & & & & Niger & -0.305 & -0.301 & -0.310 \\
\hline 107 & & & & & Angola & -0.306 & -0.456 & -0.157 \\
\hline 108 & & & & & Cameroon & -0.331 & -0.460 & -0.202 \\
\hline 109 & & & & & Papua New Guinea & -0.332 & -0.212 & -0.452 \\
\hline 110 & & & & & $\begin{array}{l}\text { Congo Democratic } \\
\text { Republic }\end{array}$ & -0.401 & -0.303 & -0.500 \\
\hline
\end{tabular}

EEII = extraregional economic integration index, GEII = global economic integration index, IEII = intraregional economic integration index Source: Authors' calculations. 
It appears that the relative contributions of the IEII and EEII for a country's full economic integration (its integration with the global economy) vary by country. Among the 103 economies reported, 51 show intraregional integration levels higher than for extraregional integration, while the reverse is true for the other 52 economies. Yet, the general picture emerging is that countries with high globalization scores also demonstrate deep intraregional integration. Indeed, the economies ranked 1st to 32 nd in 2006, with two exceptions, show greater IEII scores than EEII, implying that intraregional integration contributes more to the degree of global economic integration than extraregional integration. The two exceptions are the United Kingdom (ninth) and Malaysia (26th), where extraregional integration is more important than intraregional integration. It is interesting to see that the People's Republic of China (34th) and Japan (37th), the world's second and third largest economies, are in the same category as they exhibit higher EEll scores. The same is true for the Republic of Korea (33rd), which is another heavy manufacturing country.

The results for 2014 change little and the main implications are virtually the same. To summarize, Luxembourg; Canada; Hong Kong, China; and the Netherlands are still the top four. The rest of the top 10 is made up of EU countries except the United States (seventh) and Singapore (10th). Indeed, all $27 \mathrm{EU}$ countries score high in their levels of global integration, with Malta, ranked 34th, the weakest performer. The contributions of the IEII and EEII to the national levels of globalization vary by country: among the 110 economies reported, 54 show greater IEII scores than EEII, and 56 show the opposite. Yet, economies with high scores in globalization also show strong intraregional integration. Among EU countries, the United Kingdom is again the only exception, with the EEll higher than the IEII. For Asia's three heavy manufacturing countries (the People's Republic of China, Japan, and the Republic of Korea), extraregional integration continues to be more important than intraregional integration for the degree of global economic integration.

Figure 1 depicts the GEII, IEII, and EEIl averaged over all economies. The GEII shows an uptrend, indicating that the level of globalization has risen over time. One can also see a sharp downturn between 2008 and 2009, which must be associated with the global financial crisis. Another downturn between 2011 and 2012 seems to reflect the eurozone debt crisis. The IEII and EEII share a pattern similar to the GEII. They rise over time with the two sharp downturns clearly visible. The GEII, IEII, and EEII also hit the same troughs in 2009 and 2012. For the second downturn, though, the IEII begins to fall from 2010, possibly affected by the economic contractions in the eurozone, whereas the GEII and EEII follow suit from 2011. From 2012, the three indexes move closely together. Between the two subcomponents, the EEII produces a larger variation than the IEII over time. 
Figure 1: Intraregional, Extraregional, and Global Economic Integration Indexes, 2006-2014

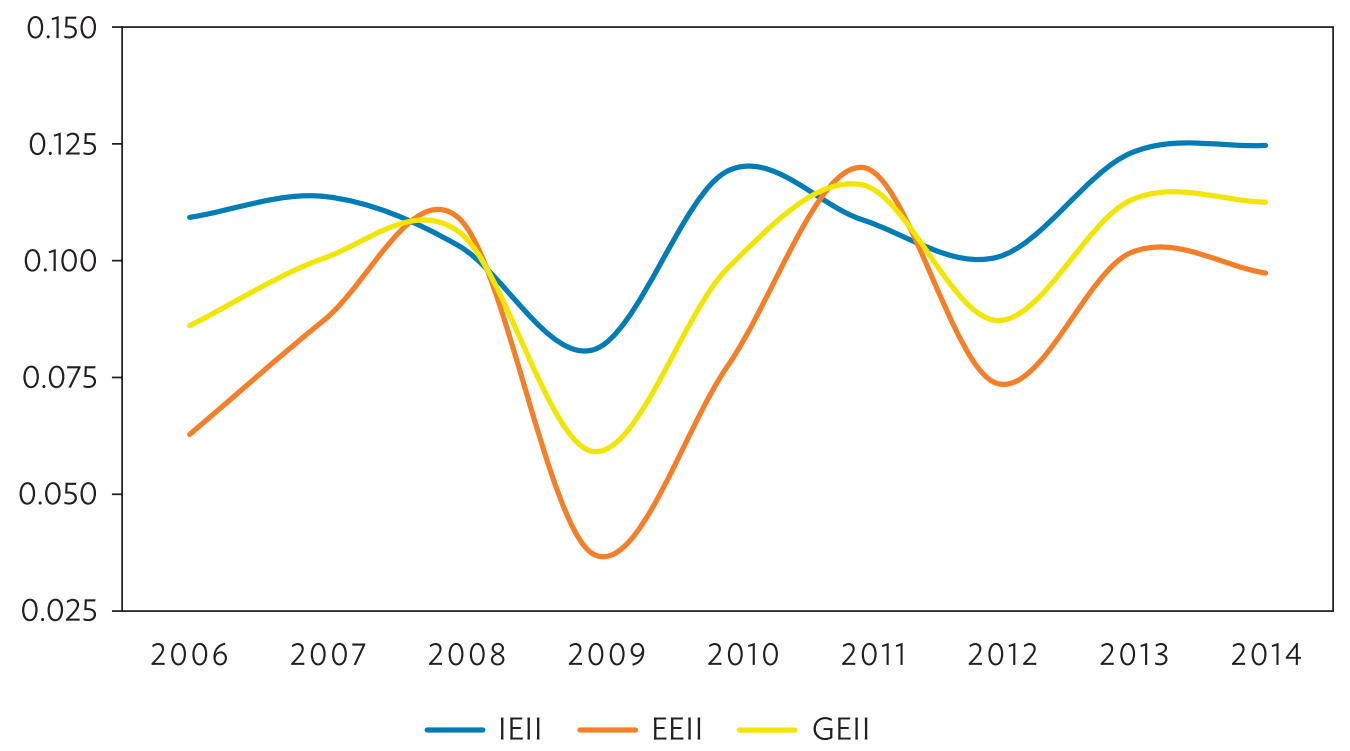

EEII = extraregional economic integration index, GEII = global economic integration index, IEII = intraregional economic integration index. Source: Authors' calculations.

Figure 2 examines whether the income level influences the degree of globalization. The World Bank's classification of countries by income (e.g., Fantom and Serajuddin 2016) categorizes each country into four groups: high income, upper-middle income, lower-middle income, and low income. In this study, the full sample of 158 economies can be grouped into 46 high-income, 40 upper-middleincome, 50 lower-middle-income, and 22 low-income economies.

The implications of Figure 2 are clear. The level of globalization is generally higher among highincome countries than other income groups. Upper-middle and lower-middle economies generally follow high-income economies in their levels of globalization, and low-income countries are the least globally integrated. Equally interesting is that high-income economies have higher IEll scores than those of the EEII, reflecting the inclusion of most European countries in the high-income group. The order is reversed in all the other income groups. 
Figure 2: Intraregional, Extraregional, and Global Economic Integration Indexes by Income Level

High income

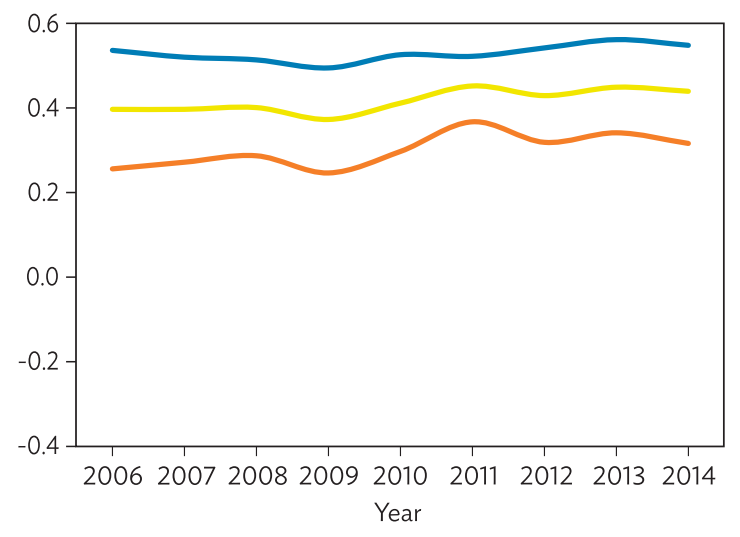

Upper-middle income

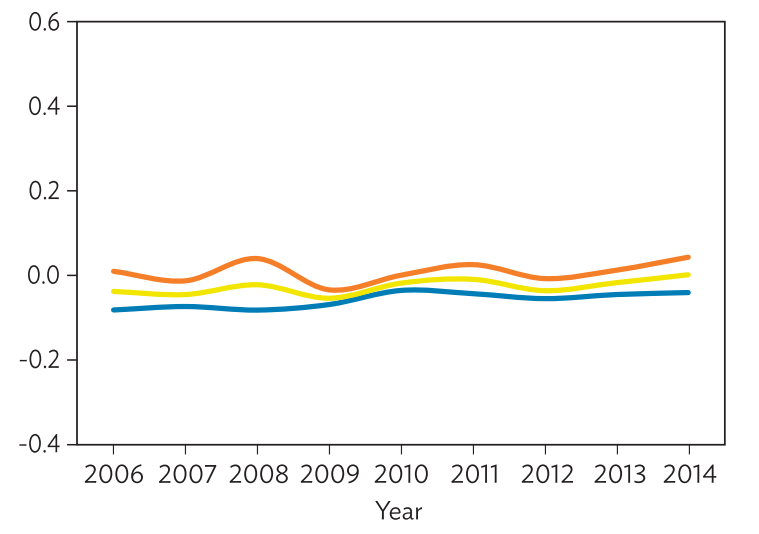

Lower-middle income

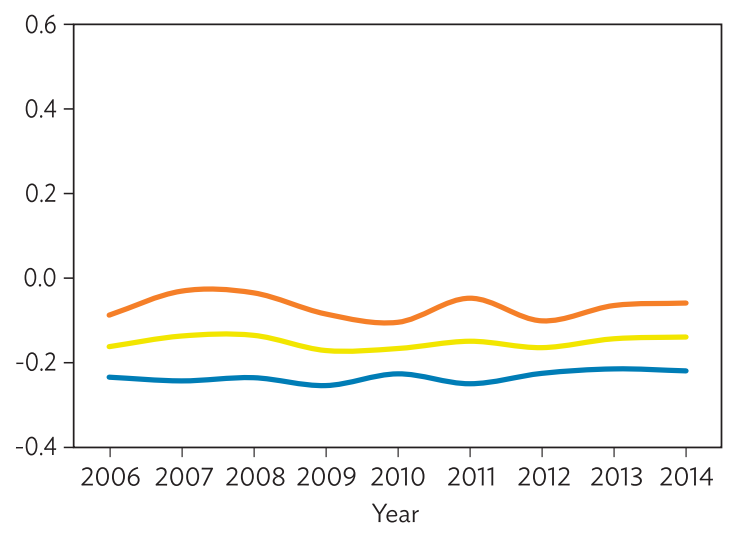

Low income

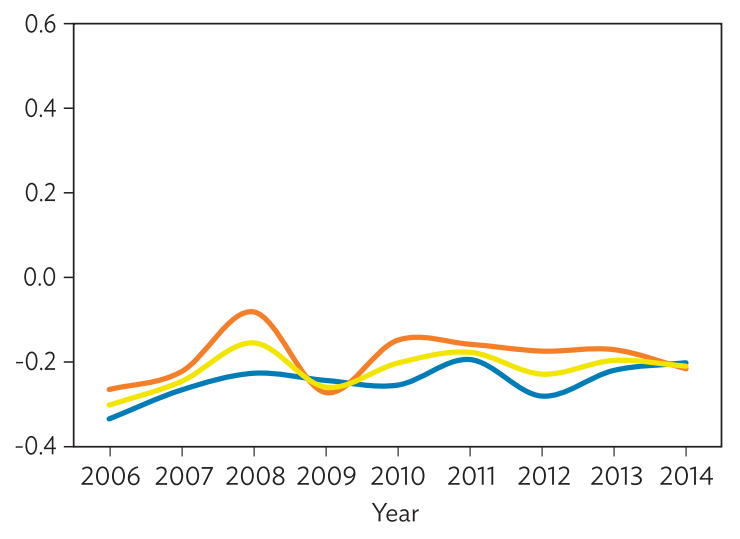

- IEII — EEII — GEII

EEII = extraregional economic integration index, GEII = global economic integration index, IEII = intraregional economic integration index. Source: Authors' calculations.

Figure 3 depicts the three indexes of globalization by region. For the GEII, North America ranks highest and the EU second. This is in line with the findings in Figure 2, since all countries in North America and the EU (besides Bulgaria and Romania) belong to the high-income group. Asia and the Pacific region ranks third, although there is a considerable gap between this region and the first two leading groups (North America and the EU). Latin America comes at fourth and Africa is the least globalized region.

Again, similar patterns are found in the results for the IEII and EEII. Irrespective of the integration type, North America is top, followed by the EU, Asia and the Pacific, Latin America, and Africa. For intraregional integration, the EU performs almost as well as North America, but the gap between the two regions widens for extraregional integration. Asia and the Pacific and Latin America exhibit a similar level of intraregional integration, particularly in the latter years. In the past few years, Latin American and African levels of extraregional integration are also comparable. 
Figure 3: Intraregional, Extraregional, and Global Economic Integration Indexes by Region

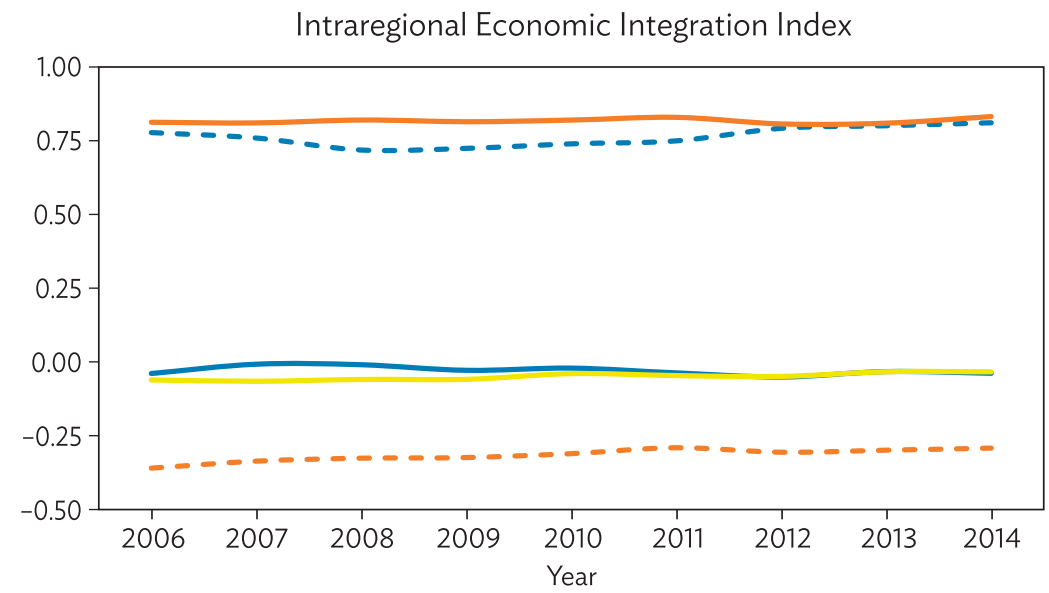

Extraregional Economic Integration Index

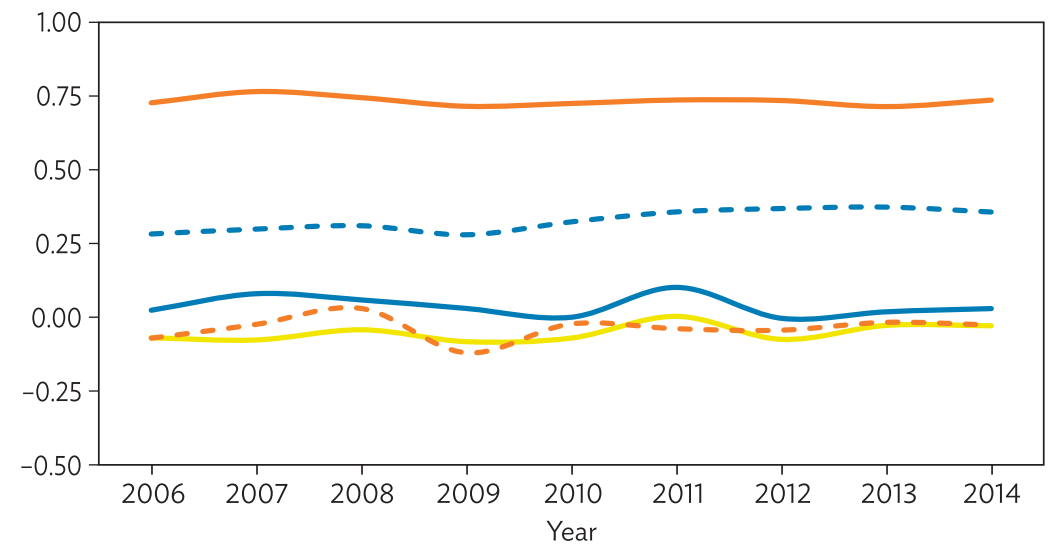

Global Economic Integration Index

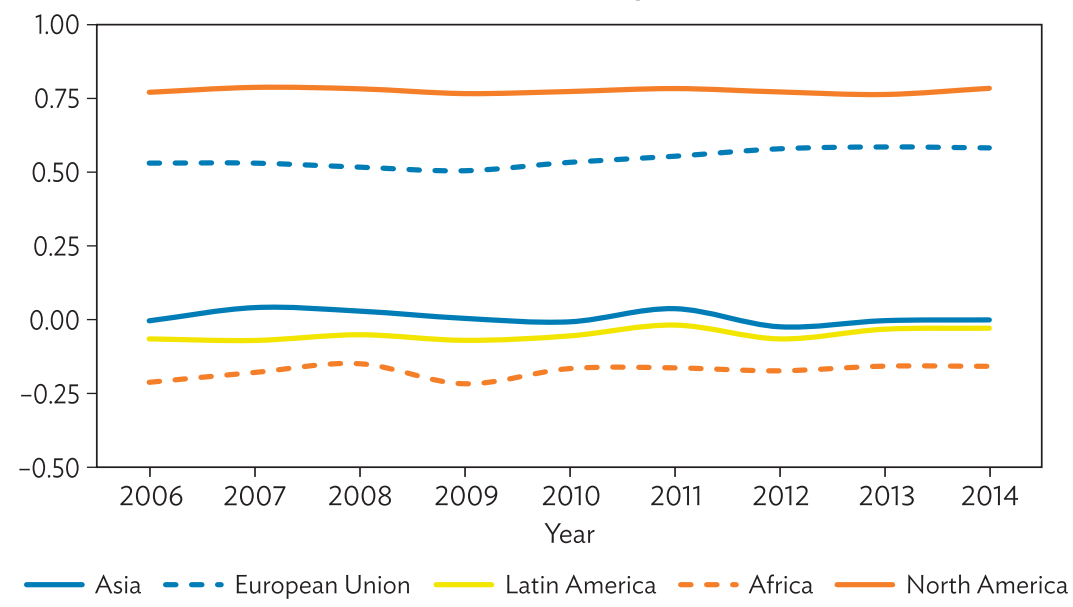


Figure 4 depicts the six-dimensional indexes of the IEII according to income. High-income economies are the most regionally integrated in all dimensions, comfortably outperforming countries in the other income groups. The upper-middle-income group ranks second in the two dimensions of infrastructure and connectivity and institutional and social integration. This observation is consistent with the view that quality infrastructure and institutions are important for economic development, although it is not to show causality between them. In the trade and investment integration dimension, the lower-middle-income group ranks second on average, followed by the upper-middle and lowincome groups. The low-income group surpasses the upper-middle and lower-middle-income groups in the movement of people, except for the last 2 years.

The value chain dimension exhibits mixed results concerning the relative strength among the upper-middle, lower-middle, and low-income groups. These three income groups show similarly low levels of attainment in the money and finance integration dimension. This finding suggests that financial market integration tends to be more challenging for developing countries where domestic financial markets and systems are yet to be fully developed and hence unlikely fully liberalized.

Figure 5 shows the corresponding dimensional indexes for the EEII. Again, high-income economies attain the highest scores across most dimensions. One notable exception is that they rank last in the trade and investment integration dimension. The upper-middle-income group tops on average in this dimension, whereas the lower-middle and low-income groups claim first place in some years. For the other five dimensions, the upper-middle-income group scores higher than both the lower-middle-income and low-income groups. A possible compromise is for the value chain dimension, where the lower-middle-income group performs better in some years at the beginning and at the end of the sample period. This may reflect the wave of outsourcing of intermediate goods production in low-wage countries in the 2000s.

Figure 6 reports the six-dimensional indexes of the IEII according to region. In the trade and investment integration dimension, the EU scores the highest intraregional integration as anticipated. More interestingly, Asia and the Pacific closely follows, with its level in 2010 being even higher than the EU. This may reflect the many initiatives and policies that Asia has implemented to deepen regional integration in trade and foreign direct investment to boost regional demand as a response to the global economic slowdown in the aftermath of the global financial crisis. The two Americas and Africa share similarly low levels of intraregional integration.

In the remaining five dimensions, North America and the EU are top, while their strengths vary across the dimensions. Latin America ranks third in most cases. Africa performs the worst, except for the institutional and social integration dimension, where Asia and the Pacific ranks last.

Figure 7 reports the corresponding six-dimensional indexes of the EEII. The results for the trade and investment integration dimension contrast sharply with those of the IEll. Africa and Latin America come out higher for extraregional integration than the two top-ranking regions-Asia and the Pacific and the EU-in the case of intraregional integration. Asia and the Pacific ranks third in the early years, while the EU takes that place in the later years. For the other five dimensions, North America and the EU are again the two top performers. North America surpasses the EU in most cases, except the money and finance integration dimension. Latin America ranks third in the two dimensions of money and finance and the free movement of people, while Asia and the Pacific ranks third in the value chain and the infrastructure and connectivity dimensions. For the institutional and social integration dimension, Africa performs marginally better than Asia and the Pacific, and Latin America ranks last. 
Figure 4: Dimensions of the Intraregional Economic Integration Index by Income Level
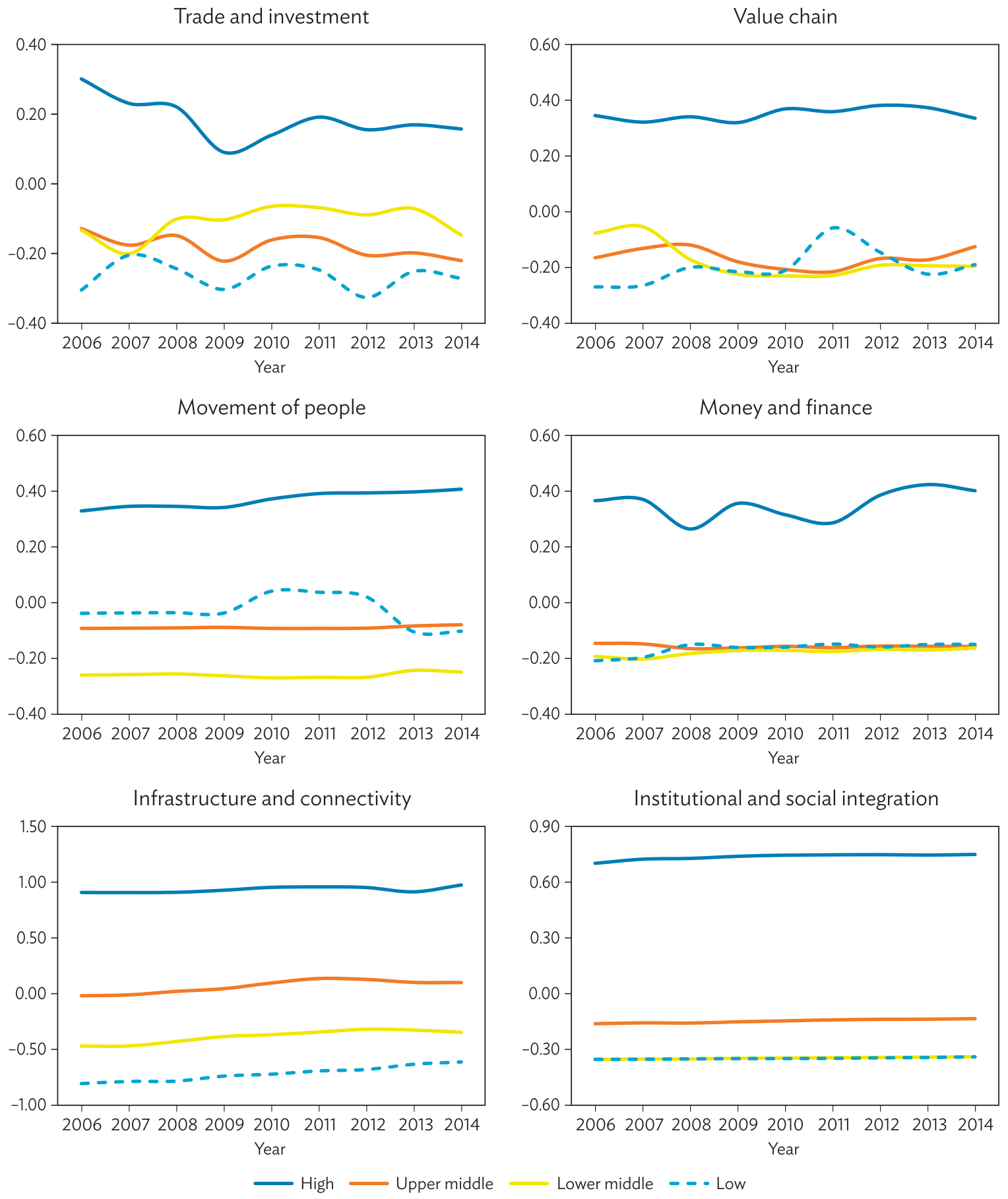

Source: Authors' calculations. 
Figure 5: Dimensions of the Extraregional Economic Integration Index by Income Level
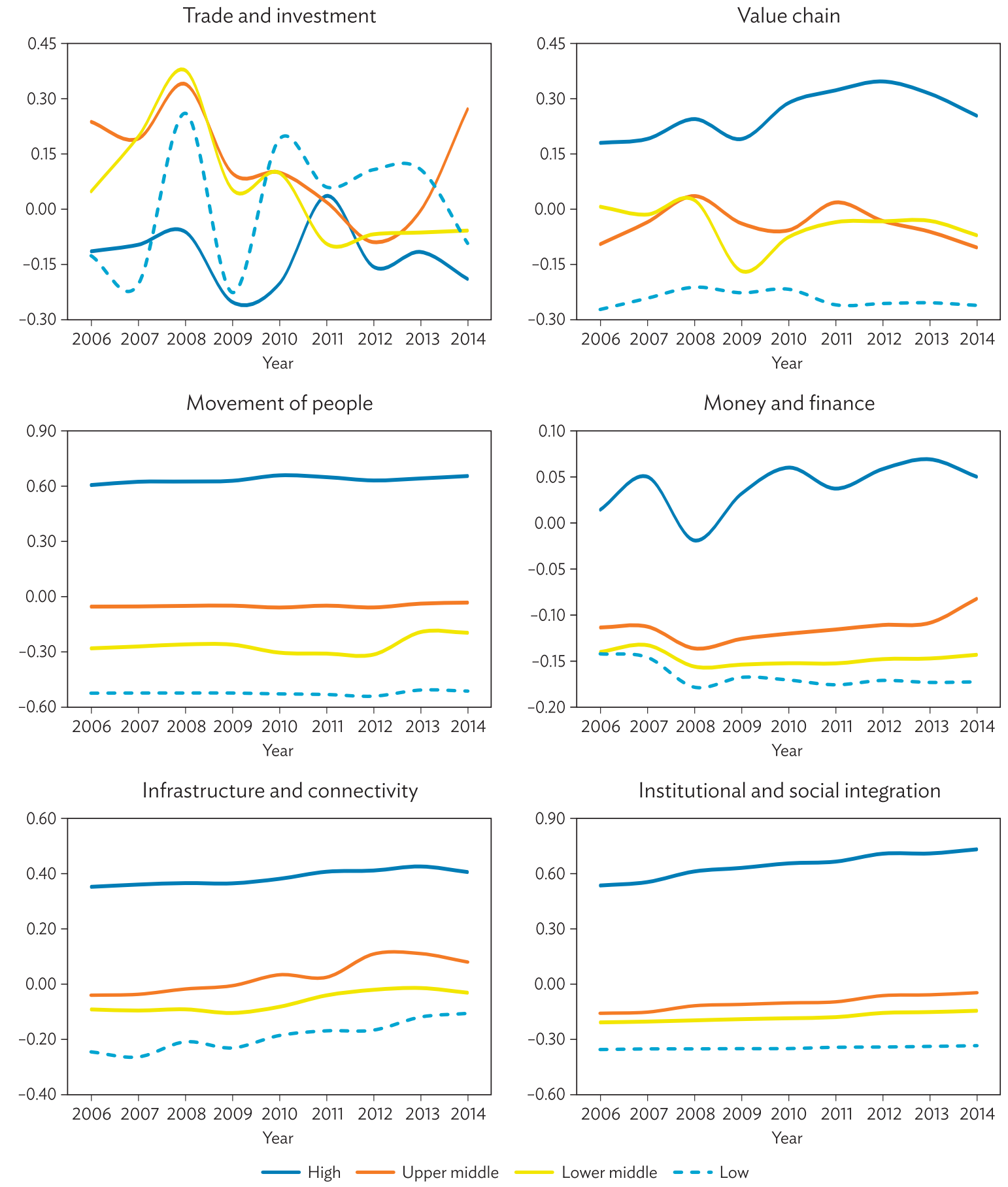

Source: Authors' calculations. 
Figure 6: Dimensions of the Intraregional Economic Integration Index by Region
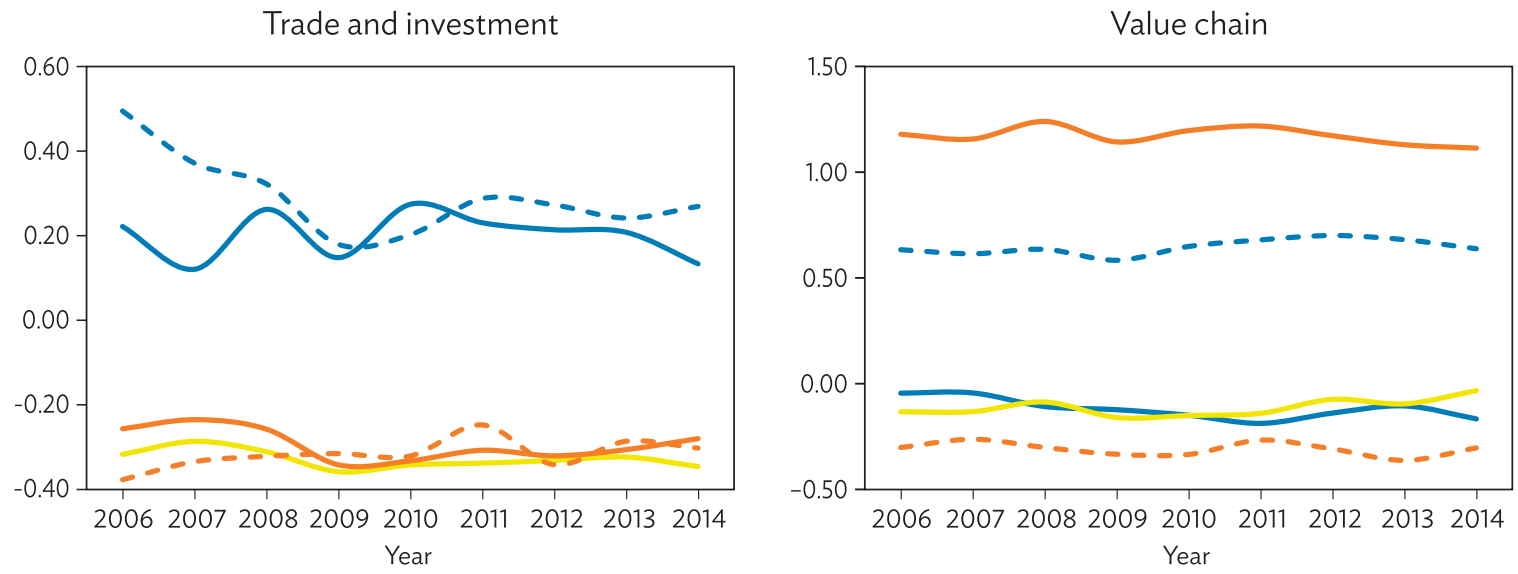

Movement of people
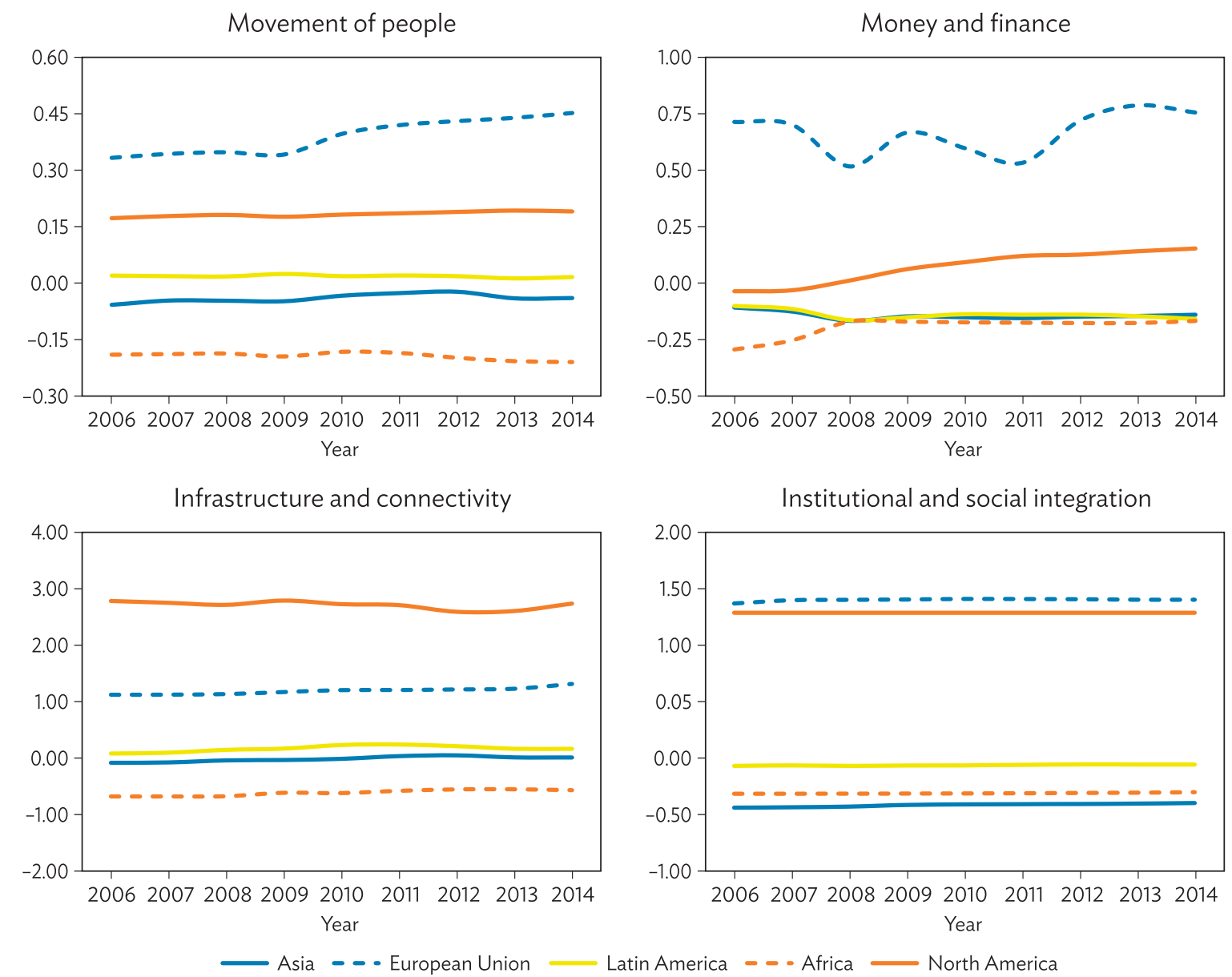

Source: Authors' calculations. 
Figure 7: Dimensions of the Extraregional Economic Integration by Region
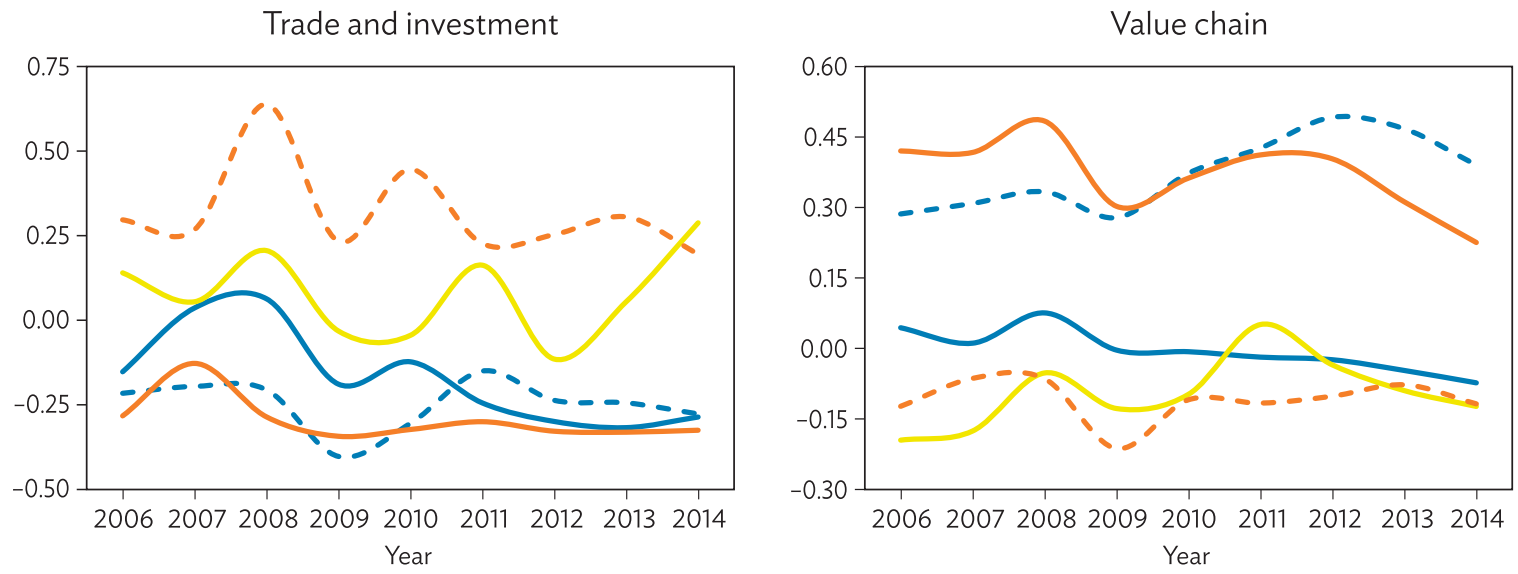

Movement of people

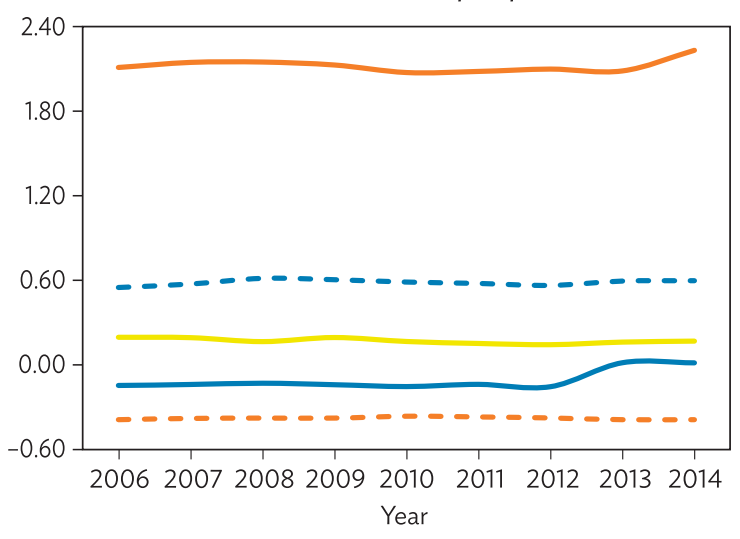

Money and finance

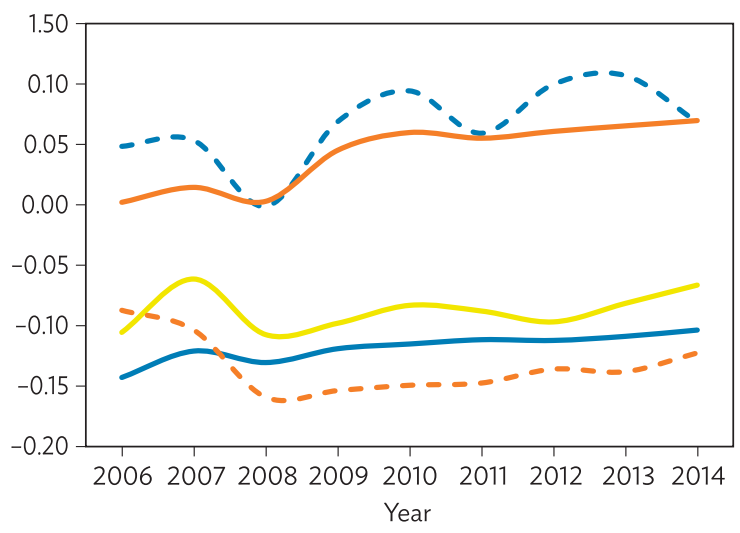

Infrastructure and connectivity
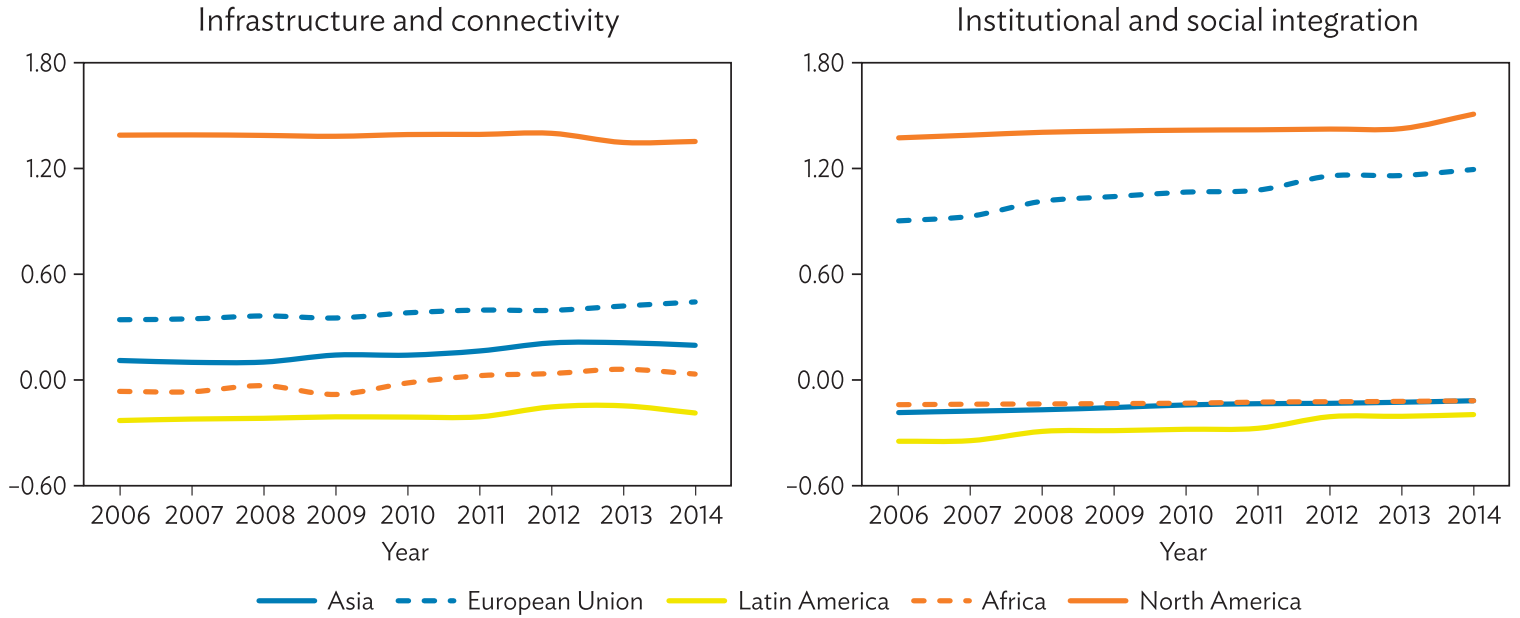

Source: Authors' calculations. 


\section{IMPLICATIONS FOR ECONOMIC GROWTH AND INCOME INEQUALITY}

Most scholars and market practitioners believe the benefits associated with globalization can exceed its costs for fostering economic growth, and this optimism is supported by the empirical results. At the same time, there is large heterogeneity in the degree of globalization across countries, as shown in the results of section $\mathrm{V}$. These differences produce disparity in economic development and growth. The different effects of globalization also have various consequences. One of the key issues is income inequality, which has severely worsened over the past 3 decades of globalization. Although many theoretical and empirical studies have evaluated the link between globalization and income inequality, the results are largely mixed for the core question of whether globalization has significantly exacerbated income inequality. Seshanna and Decornez (2003) observe that the world economy has become more unequal and polarized amid rapid globalization. Kanbur (2000) and Attanasio, Goldberg, and Pavcnik (2004) conclude that increased openness from globalization has coincided with widening income inequality for developing countries. Some European countries, amid increased international competition, have tried to reduce their welfare programs, while shifting the tax burden from mobile capital to immobile labor (Gaston and Nelson 2004, Tanzi 1995). Arguments such as these also imply that globalization worsens income inequality. By contrast, Bordo, Eichengreen, and Irwin (1999) and Rodrik (1998) argue that large welfare states adjust government aids and tax systems in ways that minimize the adverse consequences of globalization such as income inequality. Mahler (2001) finds little evidence of a systematic relationship between the main modes of globalization and distribution of household income in developed countries. Collier and Dollar (2001) estimate the decline in income inequality for developing countries.

In this section, we empirically examine the effects of globalization, first on economic growth and then on income inequality. As discussed in the Introduction, most previous studies focus on proxy variables that reflect only some dimensions of globalization. To address the associated deficiencies, the globalization indexes developed in section $\mathrm{V}$ are used to evaluate the overall effects of globalization on economic growth and income inequality. This tactic is particularly useful for the study of income inequality, in which both institutional and noneconomic factors may play a role. The presence of institutional factors highlights the need for a sufficiently broad measure of globalization rather than single proxies when investigating its effects on income inequality (Dreher, Gaston, and Martens 2008).

Economic literature has long argued that quality institutions matter for economic development by promoting certainty of the contract, reducing the costs of economic transactions, ensuring appropriability of returns to investment, and fostering business and investment friendly environment. Rodrik, Subramanian and Trebbi (2004) assess the relative importance of institutions, geography and trade in determining the income differences between developed and developing countries and find that the quality of institutions is the most significant and influential factor for economic development. Improving institutional quality (such as establishing the rule of law, improving contract enforcement and property rights, and reducing uncertainty) play a key role in delivering long-run economic development and social prosperity. Our institutional and social integration index includes the trade, investment, and taxation agreements that help set the rules in cross-border economic transactions. In addition, the number of embassies for institutionalized diplomatic relations and cultural proximity can be considered as proxies for social capital in the international setting that is often found as important noneconomic factors for economic development. 
Table 5 presents the panel regression results for the relationship between economic growth and globalization. The dependent variable is the annual growth rate of gross domestic product (GDP) per capita. As before, the sample period from 2006 to 2014, and the number of economies under study is 158. Since some of the data, including the globalization indexes, are not available for all countries or all years, the panel is unbalanced and the number of observations in the estimation depends on the choice of explanatory variables. To account for the time-invariant unobservable heterogeneity potentially correlated with the explanatory variables, a country fixed effects model is estimated.

To ensure the statistical adequacy of this specification, the benchmark model of equation (1) is tested using a Chow-type test, which assumes the null hypothesis of a pooled regression against the alternative hypothesis of a fixed effects regression. The $F$ statistic is 4.02 with degrees of freedom at 120 and 799, suggesting that the null hypothesis is strongly rejected with a marginal significance level ( $p$ value) of 0.0 in favor of the fixed effects regression. This fixed effects regression is also preferred to a country random effects regression, since the Hausman test statistic is $x 2=60.24$ with 10 degrees of freedom ( $p$ value $=0.0$ )

In the regression, either the GEII or its subcomponents of the IEII and EEII together enter as an explanatory variable. Also included are the variables typically employed in growth regressions (e.g., Barro 1997). The 1-year lagged level of GDP per capita in log (PERGDP[1]) is intended to ensure conditional convergence to its long-run level of GDP per capita. The logs of mean years of schooling (SCHOOL) and life expectancy at birth (LIFE) are used as indicators of human capital. The fertility rate in log (FERTILITY) controls for the effect that higher population growth reduces per capita economic growth. Higher domestic investment as a ratio of GDP (INVEST) should lead to higher growth rates. The ratio of government consumption to GDP (GOV_CON) approximates the outlays that do not enhance productivity, and this is expected to adversely affect economic growth (Barro 1997). A rule of law index (RULE) accounts for the quality of the legal system and enforcement of contracts and property rights. Better institutions can promote economic growth. As political stability can also improve the business and investment climate, a political stability index (STABILITY) is included. Finally, the rate of inflation (INFLATION) is added to reflect the impact of the costs associated with high inflation on economic growth. ${ }^{11}$

Equation (1) in Table 5 includes the GEII and other explanatory variables. The results show that globalization promotes economic growth. Its coefficient is positive and statistically different from zero with a $p$ value of 0.0. A 0.1-point increase in its score expands GDP per capita by 0.57 percentage points. Equation (2) shows that both the IEII and EEII foster economic growth and that all the effects are significant at the 10\% level. The results also show that the increase in GDP growth owing to the IEII (0.400) is greater than that owing to the EEII (0.220). The estimation results for the other explanatory variables are as expected with the coefficients being statistically significant at the $10 \%$ level. Higher levels of lagged GDP per capita are associated with lower growth rates. Higher government consumption and a higher fertility rate also lead to lower growth. Growth rates are higher with more years of schooling, longer life expectancy, and larger investment. A rise in the rule of law index also leads to higher economic growth, and the same is true for the political stability index. The rate of inflation has the expected negative coefficient, but it is statistically insignificant from zero. In the last

11 The data on the dependent and explanatory variables (other than the globalization indexes) are drawn from the World Bank's DataBank at http://databank.worldbank.org/. The exception is the data on SCHOOL, which are obtained from the United Nations Development Programme, Human Development Index dataset at http://www.hrd.undp.org/. All these data are available publicly. 
Table 5: Regression Results for Globalization and Economic Growth

\begin{tabular}{|c|c|c|c|c|c|c|c|c|c|c|c|c|}
\hline Equation & (1) & (2) & (3) & (4) & (5) & (6) & (7) & (8) & (9) & (10) & (11) & $(12)$ \\
\hline Coverage & \multicolumn{2}{|c|}{$\begin{array}{c}\text { All } \\
\text { Countries }\end{array}$} & \multicolumn{2}{|c|}{$\begin{array}{c}\text { High } \\
\text { Income }\end{array}$} & \multicolumn{2}{|c|}{$\begin{array}{l}\text { Upper-Middle } \\
\text { Income }\end{array}$} & \multicolumn{2}{|c|}{$\begin{array}{l}\text { Lower-Middle } \\
\text { Income }\end{array}$} & \multicolumn{2}{|c|}{$\begin{array}{c}\text { Upper } \\
\text { Income }\end{array}$} & \multicolumn{2}{|c|}{$\begin{array}{l}\text { Lower } \\
\text { Income }\end{array}$} \\
\hline GEII & $\begin{array}{l}0.568 \\
(0.00)\end{array}$ & & $\begin{array}{l}0.404 \\
(0.15)\end{array}$ & & $\begin{array}{c}1.505 \\
(0.00)\end{array}$ & & $\begin{array}{l}0.320 \\
(0.25)\end{array}$ & & $\begin{array}{l}0.797 \\
(0.00)\end{array}$ & & $\begin{array}{l}0.362 \\
(0.11)\end{array}$ & \\
\hline IEII & & $\begin{array}{l}0.400 \\
(0.02)\end{array}$ & & $\begin{array}{l}0.320 \\
(0.09)\end{array}$ & & $\begin{array}{c}1.072 \\
(0.08)\end{array}$ & & $\begin{array}{l}0.272 \\
(0.44)\end{array}$ & & $\begin{array}{l}0.509 \\
(0.00)\end{array}$ & & $\begin{array}{c}0.110 \\
(0.73)\end{array}$ \\
\hline EEII & & $\begin{array}{l}0.220 \\
(0.07)\end{array}$ & & $\begin{array}{l}0.029 \\
(0.89)\end{array}$ & & $\begin{array}{l}0.595 \\
(0.11)\end{array}$ & & $\begin{array}{l}0.124 \\
(0.47)\end{array}$ & & $\begin{array}{l}0.288 \\
(0.13)\end{array}$ & & $\begin{array}{l}0.197 \\
(0.15)\end{array}$ \\
\hline PERGDP[1] & $\begin{array}{l}-0.225 \\
(0.00)\end{array}$ & $\begin{array}{l}-0.224 \\
(0.00)\end{array}$ & $\begin{array}{l}-0.344 \\
(0.00)\end{array}$ & $\begin{array}{l}-0.344 \\
(0.00)\end{array}$ & $\begin{array}{l}-0.242 \\
(0.00)\end{array}$ & $\begin{array}{l}-0.243 \\
(0.00)\end{array}$ & $\begin{array}{l}-0.147 \\
(0.00)\end{array}$ & $\begin{array}{l}-0.147 \\
(0.00)\end{array}$ & $\begin{array}{l}-0.270 \\
(0.00)\end{array}$ & $\begin{array}{l}-0.271 \\
(0.00)\end{array}$ & $\begin{array}{l}-0.148 \\
(0.00)\end{array}$ & $\begin{array}{l}-0.149 \\
(0.00)\end{array}$ \\
\hline SCHOOL & $\begin{array}{l}0.070 \\
(0.01)\end{array}$ & $\begin{array}{l}0.071 \\
(0.01)\end{array}$ & $\begin{array}{l}0.003 \\
(0.96)\end{array}$ & $\begin{array}{l}0.007 \\
(0.89)\end{array}$ & $\begin{array}{c}0.101 \\
(0.08)\end{array}$ & $\begin{array}{l}0.106 \\
(0.07)\end{array}$ & $\begin{array}{l}0.053 \\
(0.24)\end{array}$ & $\begin{array}{l}0.052 \\
(0.24)\end{array}$ & $\begin{array}{l}0.086 \\
(0.02)\end{array}$ & $\begin{array}{l}0.090 \\
(0.02)\end{array}$ & $\begin{array}{l}0.059 \\
(0.10)\end{array}$ & $\begin{array}{l}0.059 \\
(0.10)\end{array}$ \\
\hline LIFE & $\begin{array}{l}0.145 \\
(0.05)\end{array}$ & $\begin{array}{l}0.138 \\
(0.07)\end{array}$ & $\begin{array}{l}\mathbf{0 . 8 5 6} \\
(0.00)\end{array}$ & $\begin{array}{l}0.890 \\
(0.00)\end{array}$ & $\begin{array}{c}0.115 \\
(0.35)\end{array}$ & $\begin{array}{c}0.105 \\
(0.40)\end{array}$ & $\begin{array}{c}0.136 \\
(0.20)\end{array}$ & $\begin{array}{c}0.128 \\
(0.24)\end{array}$ & $\begin{array}{l}0.262 \\
(0.01)\end{array}$ & $\begin{array}{l}0.262 \\
(0.01) \\
\end{array}$ & $\begin{array}{c}0.179 \\
(0.07)\end{array}$ & $\begin{array}{l}0.185 \\
(0.07)\end{array}$ \\
\hline FERTILITY & $\begin{array}{l}-0.102 \\
(0.00)\end{array}$ & $\begin{array}{l}-0.104 \\
(0.00)\end{array}$ & $\begin{array}{l}-0.011 \\
(0.79)\end{array}$ & $\begin{array}{l}-0.009 \\
(0.82)\end{array}$ & $\begin{array}{l}-0.063 \\
(0.39)\end{array}$ & $\begin{array}{c}-0.064 \\
(0.38)\end{array}$ & $\begin{array}{c}-0.095 \\
(0.10)\end{array}$ & $\begin{array}{c}-0.098 \\
(0.10)\end{array}$ & $\begin{array}{l}-0.061 \\
(0.09)\end{array}$ & $\begin{array}{c}-0.062 \\
(0.08)\end{array}$ & $\begin{array}{c}-0.084 \\
(0.10)\end{array}$ & $\begin{array}{c}-0.084 \\
(0.11)\end{array}$ \\
\hline INVEST & $\begin{array}{l}0.244 \\
(0.00)\end{array}$ & $\begin{array}{l}0.243 \\
(0.00)\end{array}$ & $\begin{array}{l}0.487 \\
(0.00)\end{array}$ & $\begin{array}{c}0.491 \\
(0.00)\end{array}$ & $\begin{array}{c}0.382 \\
(0.00)\end{array}$ & $\begin{array}{c}0.381 \\
(0.00)\end{array}$ & $\begin{array}{c}0.160 \\
(0.00)\end{array}$ & $\begin{array}{c}0.160 \\
(0.00)\end{array}$ & $\begin{array}{c}0.415 \\
(0.00)\end{array}$ & $\begin{array}{c}0.414 \\
(0.00)\end{array}$ & $\begin{array}{c}0.081 \\
(0.00)\end{array}$ & $\begin{array}{l}0.082 \\
(0.00)\end{array}$ \\
\hline GOV_CON & $\begin{array}{l}-0.093 \\
(0.00)\end{array}$ & $\begin{array}{l}-0.093 \\
(0.00)\end{array}$ & $\begin{array}{l}-0.824 \\
(0.00)\end{array}$ & $\begin{array}{l}-0.824 \\
(0.00)\end{array}$ & $\begin{array}{l}-0.658 \\
(0.00)\end{array}$ & $\begin{array}{l}-0.661 \\
(0.00)\end{array}$ & $\begin{array}{l}-0.039 \\
(0.20)\end{array}$ & $\begin{array}{c}-0.038 \\
(0.21)\end{array}$ & $\begin{array}{l}-0.810 \\
(0.00)\end{array}$ & $\begin{array}{l}-0.812 \\
(0.00)\end{array}$ & $\begin{array}{l}-0.058 \\
(0.05)\end{array}$ & $\begin{array}{l}-0.059 \\
(0.05)\end{array}$ \\
\hline RULE & $\begin{array}{l}3.385 \\
(0.00)\end{array}$ & $\begin{array}{l}3.362 \\
(0.00)\end{array}$ & $\begin{array}{l}5.137 \\
(0.01)\end{array}$ & $\begin{array}{l}5.063 \\
(0.01)\end{array}$ & $\begin{array}{l}3.233 \\
(0.22)\end{array}$ & $\begin{array}{l}3.228 \\
(0.22)\end{array}$ & $\begin{array}{c}1.582 \\
(0.38)\end{array}$ & $\begin{array}{l}1.608 \\
(0.38)\end{array}$ & $\begin{array}{l}4.835 \\
(0.00)\end{array}$ & $\begin{array}{l}4.844 \\
(0.00)\end{array}$ & $\begin{array}{c}1.947 \\
(0.23)\end{array}$ & $\begin{array}{c}1.954 \\
(0.23)\end{array}$ \\
\hline STABILITY & $\begin{array}{c}1.996 \\
(0.00)\end{array}$ & $\begin{array}{c}1.996 \\
(0.00)\end{array}$ & $\begin{array}{c}2.911 \\
(0.02)\end{array}$ & $\begin{array}{l}2.908 \\
(0.02)\end{array}$ & $\begin{array}{l}-0.438 \\
(0.72)\end{array}$ & $\begin{array}{l}-0.468 \\
(0.70)\end{array}$ & $\begin{array}{c}2.013 \\
(0.00)\end{array}$ & $\begin{array}{l}2.022 \\
(0.00)\end{array}$ & $\begin{array}{l}1.039 \\
(0.23)\end{array}$ & $\begin{array}{c}1.037 \\
(0.23) \\
\end{array}$ & $\begin{array}{c}1.983 \\
(0.00)\end{array}$ & $\begin{array}{c}1.977 \\
(0.00)\end{array}$ \\
\hline INFLATION & $\begin{array}{c}-0.005 \\
(0.77) \\
\end{array}$ & $\begin{array}{c}-0.005 \\
(0.78) \\
\end{array}$ & $\begin{array}{l}0.057 \\
(0.09)\end{array}$ & $\begin{array}{l}0.055 \\
(0.10)\end{array}$ & $\begin{array}{l}-0.015 \\
(0.72)\end{array}$ & $\begin{array}{c}-0.008 \\
(0.85)\end{array}$ & $\begin{array}{c}-0.014 \\
(0.41)\end{array}$ & $\begin{array}{l}-0.014 \\
(0.41)\end{array}$ & $\begin{array}{l}0.016 \\
(0.54)\end{array}$ & $\begin{array}{c}0.017 \\
(0.52)\end{array}$ & $\begin{array}{l}-0.017 \\
(0.29)\end{array}$ & $\begin{array}{l}-0.017 \\
(0.30)\end{array}$ \\
\hline $\begin{array}{l}\text { Number of observations } \\
R^{2}\end{array}$ & $\begin{array}{l}930 \\
0.50\end{array}$ & $\begin{array}{l}930 \\
0.50\end{array}$ & $\begin{array}{l}361 \\
0.57\end{array}$ & $\begin{array}{l}361 \\
0.58\end{array}$ & $\begin{array}{l}231 \\
0.59\end{array}$ & $\begin{array}{c}231 \\
0.59\end{array}$ & $\begin{array}{l}255 \\
0.48\end{array}$ & $\begin{array}{l}255 \\
0.48\end{array}$ & $\begin{array}{l}592 \\
0.59\end{array}$ & $\begin{array}{l}592 \\
0.60\end{array}$ & $\begin{array}{l}338 \\
0.45\end{array}$ & $\begin{array}{l}338 \\
0.45\end{array}$ \\
\hline
\end{tabular}

EEII = extraregional economic integration index, FERTILITY = log of fertility rate, GDP = gross domestic product, GEII = global economic integration index, GOV_CON = ratio of government consumption to GDP, IEII = intraregional economic integration index, INFLATION = inflation rate, INVEST = domestic investment as a ratio of GDP, LIFE = log of life expectancy at birth, PERGDP [1] = 1-year lagged level of GDP per capita in log, RULE = rule of law index, SCHOOL = log of mean years of schooling, STABILITY = political stability index.

Notes: The dependent variable is the growth rate of GDP per capita. Figures in parentheses are the marginal significance levels ( $p$ value) of the $t$ test statistics for the null hypothesis that the coefficient is equal to 0 . Figures highlighted in bold are statistically different from zero at the $10 \%$ level of significance.

Source: Authors' calculations. 
row, equations (1) and (2) both have an R2 statistic of 0.5, and this level of overall fitness is reasonable compared with other growth rate regressions in the literature (e.g., Barro 1997, Dreher 2006).

One of the findings in section $\vee$ was that the levels of globalization vary depending on income level. To see the possible implications of this on the relationship between globalization and economic growth, equations (3)-(8) report the results from running separate regressions for the different income groups. In high-income economies, equation (3) shows that the GEll promotes economic growth and the coefficient is significant at the 15\% level. While the evidence is rather weak, the relative contributions of the two subcomponents suggest one clear reason for this in the results of equation (4). For high-income economies, the IEII leads to higher economic growth and the effects are statistically significant. By contrast, the effects of the EEII on economic growth are very small (0.029) and not significant statistically. Upper-middle-income countries have similar results (see equations [5] and [6]). This time, the positive effect of the GEII on economic growth is statistically significant with a $p$ value of 0.0 . The IEII continues to exhibit significantly positive effects on economic growth. The EEII produces a considerably increased contribution, but the effects are only marginally significant.

Moving to the lower-middle-income countries in equations (7) and (8) draws a drastically different picture. While the GEII promotes economic growth, the effects are insignificant, and the same is true for its two subcomponents of the IEII and EEII. That is, none of these three indexes has any significant effect on economic growth. The subsequent analysis for low-income countries could yield a further and possibly stronger implication on this varying relationship between globalization and economic growth to income levels. Unfortunately, the low income group in the sample has a small number of 22 countries, most of which have many missing values. This lack of data points complicates carrying out a regression analysis for the low-income group with a reasonable level of accuracy. ${ }^{12}$ By way of a further analysis, two auxiliary income groups are set up, based on the World Bank's classification of countries into upper- and lower-income groups, where the former contains high and upper-middle-income countries, whereas the latter comprises lower-middle and low-income countries.

Equations (9)-(12) present the results for these two income groups. As expected, the findings for the upper-income countries in equations (9) and (10) confirm the earlier findings for high-income and upper-middle-income economies. The GEll significantly leads to higher economic growth and intraregional integration is the main driver, as the coefficient of the IEII is strongly significant, while that for the EEII is significant only at the $13 \%$ level. The results for lower-income countries in equations (11) and (12) also remain virtually unchanged. While the GEII, IEII, and EEII all promote economic growth, the effects are either significant only marginally or insignificant at all. Looking at the other explanatory variables in equations (3)-(12), they are signed as expected, except for STABILITY in equations (5) and (6) and INFLATION in equations (3), (4), (9), and (10). The statistical significance of the individual coefficients varies depending on the equation. For example, PERGDP[1] is statistically significant in all equations, highlighting the conditional convergence process of GDP to its long-run level. SCHOOL is not an important factor of economic growth in high-income economies, but it is in lower-income countries. FERTILITY significantly reduces economic growth in lower-income countries, while this effect is not statistically significant in high-income economies, probably in association with the trend of falling birth rates.

12 Among those 22 low-income countries, only two (Mozambique and Uganda) have a full set of data and the data availability of the remaining countries varies depending on the year. 
The next issue to tackle is whether globalization has significantly exacerbated income inequality, which is far more contentious than the relationship between globalization and economic growth. Table 6 presents the panel regression results. The dependent variable is the Gini index developed by the World Bank as a measure of income inequality. By construction, a rise in the Gini index denotes worsening income inequality. The sample period and number of countries under study are the same as before and country fixed effects are also allowed in the estimation.

Table 6: Regression Results for Globalization and Income Inequality

\begin{tabular}{|c|c|c|c|c|c|c|}
\hline Equation & (1) & (2) & (3) & (4) & (5) & (6) \\
\hline Coverage & \multicolumn{2}{|c|}{$\begin{array}{c}\text { All } \\
\text { Economies }\end{array}$} & \multicolumn{2}{|c|}{$\begin{array}{l}\text { High } \\
\text { Income }\end{array}$} & \multicolumn{2}{|c|}{$\begin{array}{l}\text { Middle } \\
\text { Income }\end{array}$} \\
\hline GEII & $\begin{array}{l}0.367 \\
(0.00)\end{array}$ & & $\begin{array}{c}0.115 \\
(0.52)\end{array}$ & & $\begin{array}{l}0.513 \\
(0.02)\end{array}$ & \\
\hline IEII & & $\begin{array}{l}0.014 \\
(0.93)\end{array}$ & & $\begin{array}{l}-0.285 \\
(0.13)\end{array}$ & & $\begin{array}{l}0.409 \\
(0.31)\end{array}$ \\
\hline EEII & & $\begin{array}{l}0.244 \\
(0.00)\end{array}$ & & $\begin{array}{l}0.302 \\
(0.04)\end{array}$ & & $\begin{array}{l}0.232 \\
(0.07)\end{array}$ \\
\hline PERGDP & $\begin{array}{r}-0.057 \\
(0.00)\end{array}$ & $\begin{array}{r}-0.055 \\
(0.00)\end{array}$ & $\begin{array}{r}-0.063 \\
(0.00)\end{array}$ & $\begin{array}{c}-0.062 \\
(0.00)\end{array}$ & $\begin{array}{c}-0.052 \\
(0.01)\end{array}$ & $\begin{array}{r}-0.053 \\
(0.01)\end{array}$ \\
\hline $\mathrm{SCHOOL}$ & $\begin{array}{l}-0.050 \\
(0.00)\end{array}$ & $\begin{array}{l}0.050 \\
(0.00)\end{array}$ & $\begin{array}{l}0.016 \\
(0.49)\end{array}$ & $\begin{array}{l}0.009 \\
(0.69)\end{array}$ & $\begin{array}{l}-0.110 \\
(0.00)\end{array}$ & $\begin{array}{l}-0.109 \\
(0.00)\end{array}$ \\
\hline GOV_AID & $\begin{array}{r}-0.075 \\
(0.03)\end{array}$ & $\begin{array}{l}0.075 \\
(0.03)\end{array}$ & $\begin{array}{l}-0.116 \\
(0.00)\end{array}$ & $\begin{array}{l}-0.117 \\
(0.00)\end{array}$ & $\begin{array}{l}0.091 \\
(0.37)\end{array}$ & $\begin{array}{l}0.093 \\
(0.37)\end{array}$ \\
\hline GOV_EDU & $\begin{array}{l}-0.411 \\
(0.00)\end{array}$ & $\begin{array}{r}-0.426 \\
(0.00)\end{array}$ & $\begin{array}{r}-0.526 \\
(0.00)\end{array}$ & $\begin{array}{l}-0.563 \\
(0.00)\end{array}$ & $\begin{array}{c}-0.562 \\
(0.05)\end{array}$ & $\begin{array}{l}-0.543 \\
(0.07)\end{array}$ \\
\hline EFFECTIVENESS & $\begin{array}{l}-1.162 \\
(0.07)\end{array}$ & $\begin{array}{l}-1.169 \\
(0.07)\end{array}$ & $\begin{array}{r}-1.666 \\
(0.01)\end{array}$ & $\begin{array}{r}-1.769 \\
(0.01)\end{array}$ & $\begin{array}{l}0.028 \\
(0.98)\end{array}$ & $\begin{array}{c}0.011 \\
(0.99)\end{array}$ \\
\hline LABOR & $\begin{array}{l}-0.431 \\
(0.00)\end{array}$ & $\begin{array}{r}-0.440 \\
(0.00)\end{array}$ & $\begin{array}{l}-0.471 \\
(0.00)\end{array}$ & $\begin{array}{r}-0.487 \\
(0.00)\end{array}$ & $\begin{array}{l}0.453 \\
(0.37)\end{array}$ & $\begin{array}{l}0.407 \\
(0.44)\end{array}$ \\
\hline $\begin{array}{l}\text { Number of observations } \\
R^{2}\end{array}$ & $\begin{array}{l}353 \\
0.50\end{array}$ & $\begin{array}{l}353 \\
0.50\end{array}$ & $\begin{array}{c}215 \\
0.58\end{array}$ & $\begin{array}{l}215 \\
0.67\end{array}$ & $\begin{array}{l}130 \\
0.52\end{array}$ & $\begin{array}{l}130 \\
0.52\end{array}$ \\
\hline
\end{tabular}

EEII = extraregional economic integration index, EFFECTIVENESS $=$ index of government effectiveness, GDP = gross domestic product, GEII = global economic integration index, GOV_AID = government payment of transfers and subsidies as a proportion of GDP, GOV_EDU = government expenditure on education as a proportion of GDP, IEII = intraregional economic integration index, $\mathrm{LABOR}$ = index of labor market regulation, PERGDP = log of GDP per capita, SCHOOL = log of mean years of schooling. Notes: The dependent variable is the Gini index as a proxy for income inequality. Figures in parentheses are the marginal significance levels ( $p$ value) of the t test statistics for the null hypothesis that the coefficient is equal to 0 . Figures highlighted in bold are statistically different from zero at the $10 \%$ level of significance.

Source: Authors' calculations.

The benchmark model of equation (1) in Table 5 is tested with the Chow-type test under the null hypothesis of a pooled regression against the alternative hypothesis of a fixed effects regression. The $F$ statistic is 122.49 with degrees of freedom at 71 and 274 , strongly rejecting the null hypothesis ( $p$ value $=0.0$ ) in favor of the fixed effects regression. This fixed effects regression is also preferred to a 
country random effects regression, since the Hausman test statistic is $\chi^{2}=45.91$ with seven degrees of freedom ( $p$ value $=0.0)$.

In addition to the indexes of globalization, the other explanatory variables in the regression are drawn from previous studies of income inequality. The log of GDP per capita (PERGDP) measures the levels of a country's economic and social development, and higher GDP per capita leads to lower income inequality. SCHOOL is an indicator of human capital. In less developed countries, where human capital is especially scarce, the gap between the wages of educated and uneducated workers is even larger. A high level of human capital is associated with low income inequality. Government expenditure on education as a proportion of GDP (GOV_EDU) is included, as it can increase the levels of human capital by equipping workers with better and more knowledge and skills through the provision of education and training. The index of government effectiveness (EFFECTIVENESS) captures the quality of public and civil services, quality of policy formulation and implementation, and credibility of the government's commitment to such policies. It is expected to play a role in lessening income inequality. Government payment of transfers and subsidies (GOV_AID) is included as a proportion of GDP since it can help redistribute income and so reduce income inequality. Rodrik (1998) and Bordo, Eichengreen, and Irwin (1999) also observe that large welfare states increase transfers and subsidies to ensure acquiescence by the potential losers from globalization.

The final explanatory variable focuses on labor markets. Its inclusion is based on the observation that increased income inequality in recent years has coincided with more decentralized wage bargaining and deunionization. Institutional changes in labor markets such as deunionization, the decentralization of collective bargaining, and labor market deregulation, can be associated with a greater incidence of low-paid employment and a widening of income inequality. To take this effect into account, we include an index of labor market regulation (LABOR), as reported in the Frasier Institute's annual Economic Freedom of the World. This composite index has six components: hiring regulations and minimum wage, hiring and firing regulations, centralized collective bargaining, hours regulations, mandated cost of worker dismissal, and conscription. The original series is adjusted such that a higher value corresponds to tighter labor market regulations. ${ }^{13}$

Equation (1) shows that globalization clearly worsens income inequality, as the coefficient of the GEII is positive and statistically different from zero with a $p$ value of 0.0 . The estimation results of equation (2) show that while both subcomponents also worsen income inequality, the IEII has a small coefficient estimate and is not statistically significant, whereas the EEII is strongly significant with a $p$ value of 0.0 . Extraregional integration turns out to be mainly responsible for increasing income inequality. Looking at the other explanatory variables, their signs are consistent with expectations and effects all significant at the 10\% level. Income inequality lessens with increases in GDP per capita, mean years of schooling, government payments of transfers and subsidies, government expenditure on education, government effectiveness, and labor market regulations. Equations (1) and (2) both exhibit an $R^{2}$ statistic of 0.5 in the last row.

In the same way as for economic growth, the question of whether the relationship between globalization and income inequality changes with income levels is also examined. At the outset, it must be stated that the Gini index is not available for all countries or all years, and this is particularly so for

13 The data sources are as follows: Gini index, PERGDP, GOV_EDU, and EFFECTIVENESS from the World Bank DataBank at http://databank.worldbank.org/; SCHOOL from the United Nations Development Programme, Human Development Index dataset at http://www.hrd.undp.org/; and GOV_AID and LABOR from the Frasier Institute's Economic Freedom of the World dataset at https://www.fraserinstitute.org/. All these data are available publicly. 
low-income countries. The same is also true for other explanatory variables including the globalization index. Lack of data prevents regression analysis on groups with lower-middle and low incomes. To ensure a reasonable number of observations is included in the estimation, the focus is on high- and middle-income groups, the latter constructed by combining data from upper-middle-income and lower-middle-income countries. Equations (3) and (4) report the results for high-income economies. There are notable differences in the results from the sample of all countries. Globalization worsens income inequality, but the overall effects are not statistically significant. Interestingly, intraregional integration acts to lessen, not worsen, income inequality - although the effects are insignificant at the $10 \%$ level $(p$ value $=0.13)$. Extraregional integration is the main cause of income inequality, as the coefficient is positive and statistically significant. The results for the combined middle-income countries change in equations (5) and (6), as globalization exacerbates income inequality significantly. However, even in this case, the adverse influence of intraregional integration is not statistically significant, and extraregional integration continues to be mainly responsible for income inequality. Although data points on low-income countries are insufficient to derive a more concrete implication about the relationship between globalization and income inequality, one finding is that globalization worsens income inequality, and while the effects are less pronounced in higher-income countries, lower-income countries are affected significantly.

\section{CONCLUSIONS}

Globalization has been considered as an irreversible trend that improves both incomes and nonincome aspects such as security, political stability, sociocultural harmonization, democratization, and public sensitivity to human rights and gender equality. Advocates for globalization argue that these developments have led to economic growth and human development (United Nations Development Programme 1999). Accordingly, globalization has been set forth as a key strategy for economic growth and human development in economies around the world, but there is growing criticism that it has contributed to widening inequality across and within countries and has created new threats to security and social stability.

In response to the recent backlash to globalization, regional integration has gathered pace. As countries in common supply chains increasingly carve out regional trade agreements, many countries - particularly smaller developing ones - seek regional integration to continue to benefit from multilateral trade while mitigating the potential adversities of globalization.

The costs and benefits of economic integration underscore the importance of an appropriate measure of economic integration for different layers of geographic groupings. Several studies have developed composite indexes to quantify the complex and multidimensional aspects of globalization. However, none of them has measured the accumulation of regionalization in relation to globalization (Dreher et al. 2010, Martens et al. 2015, Vujakovic 2009). In these conditions, the present study proposes the new GEII using the bilateral data to build up the layers of economic integration for each country. Its value is that it can distinguish the contributions of intraregional and extraregional integration in promoting globalization. Two composite indexes of intraregional and extraregional economic integration are combined to form the GEll, comprising 25 indicators classified into six dimensions and weighted to yield the overall index of global economic integration. This information can be used to compare strengths and weaknesses across different aspects of economic integration and for identifying gaps and sources more accurately. This in turn can help inform policy decisions on how best to meet aspirations and commitments for globalization. 
The empirical results show that the top 10 most globalized economies are six EU countries, two in Asia and the Pacific (Hong Kong, China; Singapore) and Canada and the United States. The remaining EU countries also rank high. As for the origin of globalization, about one half of the sample countries show levels of intraregional integration higher than their extraregional integration, while the other half indicate the opposite. However, a general finding is that economies with high globalization scores also exhibit strong intraregional integration, with the notable exception of the United Kingdom. Levels of globalization are highest in high-income economies followed by upper-middle, lower-middle, and low-income countries. The high-income group outperforms other income groups in all six dimensions of the indexes, except the extraregional integration measure of trade and investment, where it fares the worst. Rankings of the other income groups across the dimensions generally accord with their levels of income. By region, North America and the EU are the two top performers across all but two of the dimensions of intraregional and extraregional integration. Asia and the Pacific and Latin America compete for third place and Africa ranks last on most dimensions.

The adoption of broad composite indexes to measure how globalization affects economic growth and income inequality can be preferable to using single proxies for globalization, especially when studying the relationship between globalization and income inequality. Panel regression results in this paper show that globalization significantly promotes economic growth and that intraregional integration is the main driver. The effects are particularly pronounced in upper-income countries. The positive effect on economic growth weakens as income lowers.

The results also show that globalization exacerbates income inequality, and they support the observation that income inequality has severely worsened in tandem with rapid globalization. As with economic growth, the effects on income equality become more severe as income falls. Between the two types of integration measures, extraregional integration turns out to be mainly responsible for the increase in income inequality.

Taking the results on economic growth and income inequality together yields favorable news for high-income economies: Globalization strongly promotes economic growth, and the adverse effect on income inequality is less pronounced. However, the news is not so welcome for low-income countries, as the positive effect of globalization on their economic growth is weak, and globalization is shown to widen income inequality significantly.

Such results put developing countries-especially those wishing to take advantage of globalization to pursue economic and social development-in a difficult position for which there is no easy solution. How developing countries can deal with the arguably irreversible trend of globalization will entail many detailed studies beyond the scope of the research presented here. Nevertheless, one macrolevel policy implication that emerges from this paper is related to the relative contributions of intraregional and extraregional integration to the process of globalization.

Overall, intraregional integration is shown to be more effective at fostering economic growth, while its role in the concurrent rise in income inequality is not significant. That said, the results show that developing countries are more concentrated on activities with countries outside their own regions, particularly for trade and investment. Intraregional integration in developing countries is far behind that of high-income economies, particularly in areas beyond trade itself. As shown, regional integration in infrastructure, connectivity, and institutional arrangements is equally important, particularly for creating environments that can better accommodate the demands of globalization. All these aspects may require a shift of policy orientation toward deepening regional integration as a stepping stone for global integration. 


\section{APPENDIX 1: DATA DESCRIPTION}

The global economic integration index has two subcomponents. The intraregional economic integration index (IEII) is closely related to Huh and Park's (2018) regional integration index for economies in Asia and the Pacific and countries outside that region. ${ }^{14}$ On the other hand, the extraregional economic integration index is constructed in a parallel way, using the same indicators but to measure integration with countries outside the region. Accordingly, the IEII and EEII share the same indicators (i.e., IV-3i=IV-3e and IV-4i=IV-4e). Below lists the indicators that require elaboration beyond the information in Table 1.

\section{I-3i/I-3e: Intraregional/Extraregional Trade Intensity Index}

For a country, the indicators $\mathrm{I}-3 \mathrm{i}$ and $\mathrm{I}-3 \mathrm{e}$ are calculated as the ratio of two trade shares. For I-3i, the numerator is the country's intraregional goods trade over its total goods trade, while the denominator is the region's total goods trade over world total goods trade. I-3e has a country's extraregional goods trade over its total goods trade as the numerator and the total goods trade of all other regions over world total goods trade as the denominator. Trade refers to exports plus imports.

\section{VI-5i/VI-5e: Cultural Proximity with Intraregional/Extraregional Countries Relative to All Countries}

According to data from Centre d'Etudes Prospectives et d'Informations Internationales (CEPII), eight categories characterize the cultural proximity between countries: whether the two countries are contiguous, share a common official language, have at least $9 \%$ of their populations speaking the same language, had a mutual colonizer after 1945, have had a colonial link, had a colonial relationship after 1945, currently have a colonial relationship, and were or are the same country. To construct VI-5i (VI-5e), a country receives one point for each affirmative answer in these eight categories. The points are then averaged over all intraregional (extraregional) countries and all countries worldwide. The ratio of these two averages yields the final VI-5i $(\mathrm{VI}-5 \mathrm{e})$ data.

14 We tested for the correlation and Spearman rank correlation between IEII and Huh and Park's (2018) regional integration index for economies in Asia and the Pacific. The correlation (or Spearman rank correlation in the parenthesis, respectively) between IEII and their index is 0.81 (0.84) over the period 2006-2014, and for each year of this period, the two have a correlation in the range of $0.77(0.82)$ and $0.84(0.86)$. 


\section{APPENDIX 2: LIST OF ECONOMIES}

This study covers five geographic regions (Africa, Asia and the Pacific, the European Union, Latin America, and North America). The economies included in each region are as follows (number of economies in parentheses):

\section{Africa (49):}

Algeria, Angola, Benin, Botswana, Burkina Faso, Burundi, Cameroon, Cape Verde, Central African Republic, Chad, Comoros, Cote d'Ivoire, Democratic Republic of the Congo, Djibouti, Equatorial Guinea, Eritrea, Eswatini, Ethiopia, Gabon, The Gambia, Ghana, Guinea, Guinea-Bissau, Kenya, Lesotho, Liberia, Madagascar, Malawi, Mali, Mauritius, Morocco, Mozambique, Namibia, Niger, Nigeria, Republic of the Congo, Rwanda, São Tomé and Príncipe, Senegal, Seychelles, Sierra Leone, South Africa, Sudan, Tanzania, Togo, Tunisia, Uganda, Zambia, Zimbabwe

Asia and the Pacific (48):

Afghanistan; Armenia; Australia; Azerbaijan; Bangladesh; Bhutan; Brunei Darussalam; Cambodia; Cook Islands; Federated States of Micronesia; Fiji; Georgia; Hong Kong, China; India; Indonesia; Japan; Kazakhstan; Kiribati; Kyrgyz Republic; Lao People's Democratic Republic; Malaysia; Maldives; Marshall Islands; Mongolia; Myanmar; Nauru; Nepal; New Zealand; Pakistan; Palau; Papua New Guinea; People's Republic of China; Philippines; Republic of Korea; Samoa; Singapore; Solomon Islands; Sri Lanka; Taipei,China; Tajikistan; Thailand; Timor-Leste; Tonga; Turkmenistan; Tuvalu; Uzbekistan; Vanuatu; Viet Nam

\section{European Union (27):}

Austria, Belgium, Bulgaria, Cyprus, Czech Republic, Denmark, Estonia, Finland, France, Germany, Greece, Hungary, Ireland, Italy, Latvia, Lithuania, Luxembourg, Malta, Netherlands, Poland, Portugal, Romania, Slovak Republic, Slovenia, Spain, Sweden, United Kingdom

\section{Latin America (32):}

Antigua and Barbuda, Argentina, Bahamas, Barbados, Belize, Bolivia, Brazil, Chile, Colombia, Costa Rica, Dominica, Dominican Republic, Ecuador, El Salvador, Grenada, Guatemala, Guyana, Haiti, Honduras, Jamaica, Mexico, Nicaragua, Panama, Paraguay, Peru, Saint Kitts and Nevis, Saint Lucia, Saint Vincent and the Grenadines, Suriname, Trinidad and Tobago, Uruguay, Venezuela

North America (2):

Canada, United States 


\section{APPENDIX 3: TREATMENT OF MISSING DATA ${ }^{15}$}

The absence of data is a prevalent problem when working with many countries and indicators. Typically, some data are not available for all countries or all years. Missing data can make the composite index less reliable for countries where only limited information is available. This study is no exception, as all dimensions besides VI include indicators with missing data. In principle, neither the dimensional index nor the overall index for countries with missing data are computed. However, several times, the problem of missing data needs to be resolved to secure a minimum number of countries for the calculation of the composite indexes, which also occurs in most similar studies.

First, the indicator IV-2 with United Nations Conference on Trade and Development's liner shipping bilateral connectivity index ( $\mathrm{LSBCl}$ ) is calculated, which measures the integration of a country pair into global liner shipping networks. ${ }^{16}$ The $\mathrm{LSBCl}$ is unavailable for landlocked countries. ${ }^{17}$ Since these countries do not have access to open oceans, there may be no discernible gain in their shipping connectivity with regional trading partners or trading partners outside the region over all trading partners in the world. For this reason, it is assumed that both IV-2i and IV-2e have a value of 1 for all landlocked countries.

Second, the World Bank produces the Logistic Performance Index (overall, LPI) in IV-3 only for even years. The data for odd years are constructed by averaging the LPI data in their respective two neighboring even years. Since the LPI is unavailable for some countries, the missing values are imputed if those countries have values in the Doing Business Index (DBI) in IV-4, which is also developed by the World Bank. ${ }^{18}$ The LPI and DBI measures assess infrastructure levels from different aspects: the former examines the time and costs associated with logistics processes when transporting goods across borders, while the latter primarily examines general business conditions, such as the time and costs for setting up a business, connecting utilities, registration, and so on. Yet, the two indexes are strongly related with a correlation coefficient of 0.76 . Given this association, a simple regression is utilized to impute the missing data in the LPI. The pooled regression results are:

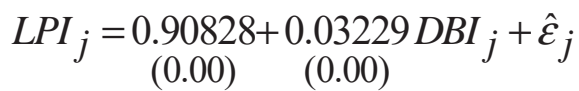

$$
\text { Adjusted } R^{2}=0.58 \quad F=2096.14[0.00] \text {, }
$$

where the figure in parentheses (squared brackets) is the $p$ value for the $t(F)$ test of statistical significance. The estimated coefficients are correctly signed and statistically significant, with $p$ values

15 In this section, intraregional and extraregional indicators are not distinguished unless necessary, since they share the same dataset.

16 The $\mathrm{LSBCl}$ is composed by arithmetically averaging five indicators.

17 Thirty-four countries in the sample are landlocked: Afghanistan, Armenia, Austria, Azerbaijan, Bhutan, Bolivia, Botswana, Burkina Faso, Burundi, Central African Republic, Chad, Czech Republic, Eswatini, Ethiopia, Hungary, Kazakhstan, Kyrgyz Republic, Lao People's Democratic Republic, Lesotho, Luxembourg, Malawi, Mali, Mongolia, Nepal, Niger, Paraguay, Rwanda, Slovak Republic, Tajikistan, Turkmenistan, Uganda, Uzbekistan, Zambia, and Zimbabwe.

18 The overall LPI is computed by averaging six indicators with weights chosen by principal component analysis, whereas the overall $\mathrm{DBI}$ is computed by arithmetically averaging 10 indicators. 
around 0 . A group of 19 countries have observations for the DBI but not the LPI. ${ }^{19}$ Their missing values for the LPI are computed by substituting the respective $\mathrm{DBI}$ values into the regression of $L P I=0.90828+0.03229 * D B I$.

Third, the bilateral migration data used in V-1 are published every 5 years, and therefore only data for 2010 and 2015 in the sample period are available. Data spanning 2005-2016 are linearly interpolated bilateral migration data from years other than 2010 and 2015, interpolated to construct $\vee-1 i$ and $\mathrm{V}-1 e$.

Fourth, since no historic data was found indicating entry visa requirements to use in the construction of $\mathrm{V}-4 \mathrm{i}$ and $\mathrm{V}-4 \mathrm{e}$, the data for 2016 across the sample years was used.

Finally, there are countries with missing observations only at the beginning and/or end of the period. In some cases, the missing observations are substituted by the closest observation available. In effect, the last nonmissing observation is taken backward (forward) in the case of missing observations at the beginning (end) of an indicator. This is similar to the technique used by Gygli, Haelg, and Sturm (2018) in their updates for the KOF Index of Globalization.

19 Antigua and Barbuda, Barbados, Belize, Cape Verde, Dominica, Eswatini, Federated States of Micronesia, Grenada, Kiribati, Marshall Islands, Palau, Samoa, Seychelles, Saint Kitts and Nevis, Saint Lucia, Saint Vincent and the Grenadines, Suriname, Tonga, and Vanuatu. 


\section{REFERENCES}

Aghion, Philippe, and Jeffrey G. Williamson. 1998. Growth, Inequality and Globalization: Theory, History and Policy. Cambridge: Cambridge University Press.

A.T.Kearney/Foreign Policy. 2002. Globalization Index. Washington DC: Carnegie Endowment for International Peace.

Attanasio, Orazio, Pinelopi K. Goldberg, and Nina Pavcnik. 2004. "Trade Reforms and Wage Inequality in Colombia.” Journal of Development Economics 74 (2): 331-66.

Baldwin, Richard. 1989. “On the Growth Effects of 1992.” Economic Policy 4 (9): 247-81.

Barro, Robert. 1997. Determinants of Economic Growth: A Cross-Country Empirical Study. Cambridge, MA: MIT Press.

Beckfield, Jason. 2006. "European Integration and Income Inequality." American Sociological Review 71 (6): 964-85.

Bo, Chen, and Yuen Pau Woo. 2008. "A Composite Index of Economic Integration in the Asia-Pacific Region.” New York: United Nations Public Administration Network. http://unpan1.un.org/intradoc/groups/public/documents/apcity/unpan049069.pdf.

Bordo, Michael, Barry Eichengreen, and Douglas Irwin. 1999. "Is Globalization Today Really Different from Globalization a Hundred Years Ago?” Brookings Trade Forum 1999, 1-72.

Bourguignon, François. 2016. "Inequality and Globalization: How the Rich Get Richer as the Poor Catch Up.” Foreign Affairs (Council on Foreign Relations) 95 (1): 11-15.

Bureau Van Dijk. https://www.bvdinfo.com/.

Centre d'Études Prospectives et d'Informations Internationales (CEPII). www.cepii.fr.

Collier, Paul, and David Dollar. 2001. "Can the World Cut Poverty in Half? How Policy Reform and Effective Aid Can Meet International Development Goals." World Development 29 (11): 1787-802.

Darku, Alexander Bilson, and Richard Yeboah. 2018. "Economic Openness and Income Growth in Developing Countries: A Regional Comparative Analysis." Applied Economics 50 (8): 855-69.

DiCaprio, Alisa, Amelia U. Santos-Paulino and Maria V. Soklova. 2017. "Regional Trade Agreements, Integration and Development." UNCTAD Research Paper No. 1.

Dollar, David. 1992. "Outward-Oriented Developing Countries Really Do Grow More Rapidly: Evidence from 95 LDCs, 1976-85." Economic Development and Cultural Change 40 (3): 523-44.

_. 2005. "Globalization, Poverty, and Inequality since 1980." World Bank Research Observer 20 (2): 145-75. 
Dollar, David, and Aart Kraay. 2002. "Growth is Good for the Poor." Journal of Economic Growth 7 (3): 195-225. https://doi.org/10.1023/A:1020139631000.

_. 2004. "Trade, Growth, and Poverty.” The Economic Journal 114 (493): F22-F49.

Dreher, Axel. 2006. “Does Globalization Affect Growth?” Applied Economics 38 (10): 1091-110.

Dreher, Axel, Noel Gaston, and Pim Martens. 2008. Measuring Globalisation: Gauging Its Consequences. New York: Springer Science and Business Media.

Dreher, Axel, Noel Gaston, Pim Martens, and Lotte Van Boxem. 2010. "Measuring GlobalizationOpening the Black Box: A Critical Analysis of Globalization Indices." Journal of Globalization Studies 1 (1): 166-85.

Edwards, Sebastian. 1992. "Trade Orientation, Distortions and Growth in Developing Countries." Journal of Development Economics 39 (1): 31-57.

_. 1993. "Openness, Trade Liberalization, and Growth in Developing Countries." Journal of Economic Literature 31 (3): 1358-93.

Fantom, Neil, and Umar Serajuddin. 2016. "The World Bank's Classification of Countries by Income.” World Bank Policy Research Working Paper No. 7528.

fDi Markets. www.fdimarkets.com.

Foreign Affairs. Different years. https://www.foreignaffairs.com/.

Frankel, Jeffrey A., and David Romer. 1996. "Trade and Growth: An Empirical Investigation.” NBER Working Paper No. w5476.

Frasier Institute. Economic Freedom of the World dataset. https://www.fraserinstitute.org/.

Gaston, Noel, and Douglas Nelson. 2004. "Structural Change and the Labour Market Effects of Globalization." Review of International Economics 12 (5): 769-92.

Gozgor, Giray, and Priya Ranjan. 2017. "Globalisation, Inequality and Redistribution: Theory and Evidence." The World Economy 40 (12): 2704-51.

Grossman, Gene, and Elhanan Helpman. 1991. "Trade, Knowledge Spillovers and Growth." European Economic Review 35 (2-3): 517-26.

Gwartney, James, and Robert Lawson. 2001. Economic Freedom of the World: 2001 Annual Report. http://www.freetheworld.org/.

Gygli, Savina, Florian Haelg, and Jan-Egbert Sturm. 2018. "The KOF Globalization Index-Revisited.” KOF Working Paper No. 439. 
Haass, Richard N., and Robert Litan. 1998. "Globalization and Its Discontents: Navigating the Dangers of a Tangled World." Foreign Affairs 77 (2): 2-5.

Harrison, Ann. 1996. "Openness and Growth: A Time-Series, Cross-Country Analysis for Developing Countries.” Journal of Development Economics 48 (2): 419-47.

Harrison, Ann, and Gordon Hanson. 1999. "Who Gains from Trade Reform? Some Remaining Puzzles." Journal of Development Economics 59 (1): 125-54.

Hu, Fred, and Michael Spence. 2017. "Why Globalization Stalled and How to Restart It." Foreign Affairs (Council on Foreign Relations) 96 (4): 54-63.

Huh, Hyeon-Seung, and Cyn-Young Park. 2018. "Asia and the Pacific Regional Integration Index: Construction, Interpretation, and Comparison.” Journal of Asian Economics 54: 22-38.

Jackson, J. Edward. 1991. A User's Guide to Principal Components. Hoboken, NJ: John Wiley \& Sons.

Johnson, Richard, and Dean Wichern. 2007. Applied Multivariate Statistical Analysis. London: Pearson.

Jolliffe, Ian T. 2002. Principal Component Analysis. Berlin: Springer-Verlag.

Kanbur, Ravi. 2000. "Income Distribution and Development." In Handbook of Income Distribution, Vol. 1, edited by Anthony B. Atkinson and François Bourguignon, 791-841. Amsterdam: Elsevier North-Holland.

Lockwood, B., and M. Redoano. 2005. "The CSGR Globalization Index: An Introductory Guide, Center for the Study of Globalisation and Regionalisation.” University of Warwick Working Paper No. $155 / 04$.

Mahler, Vincent A. 2001. "Economic Globalization, Domestic Politics and Income Inequality in the Developed Countries: A Cross-national Analysis." Luxembourg Income Study Working Paper No. 273.

Martens, Pim, Marco Caselli, Philippe De Lombaerde, Lukas Figge, and Jan Aart Scholte. 2015. "New Directions in Globalization Indices." Globalizations 12 (2): 217-28.

Martens, Pim, and Daniel Zywietz. 2006. “Rethinking Globalization: A Modified Globalization Index.” Journal of International Economics 18 (3): 331-50.

Milanovic, Branko. 2016. Global Inequality: A New Approach for the Age of Globalization. Cambridge, MA: The Belknap Press of Harvard University Press.

Nardo, Michela, Michaela Saisana, Andrea Saltelli, and Stefano Tarantola. 2011. Tools for Composite Indicators Building. Mauritius: European Commission, Dictus Publishing.

Organisation for Economic Co-operation and Development (OECD). 2008. Handbook on Constructing Composite Indicators: Methodology and User Guide. Paris: OECD, Joint Research Centre European Commission. 
Panagariya, Arvind. 2004. "Miracles and Debacles: In Defence of Trade Openness." The World Economy 27 (8): 1149-71. https://doi.org/10.1111/j.1467-9701.2004.00650.

Park, Cyn-Young, and Racquel Claveria. 2018a. "Constructing the Asia-Pacific Regional Cooperation and Integration Index: A Panel Approach.” ADB Economics Working Paper Series No. 544.

- 2018b. "Does Regional Integration Matter for Inclusive Growth? Evidence from the Multidimensional Regional Integration Index.” ADB Economics Working Paper Series No. 559.

Potrafke, Niklas. 2014. “The Evidence on Globalization.” CESifo Working Paper Series No. 4708.

Ravallion, Martin. 2018. "Inequality and Globalization: A Review Essay.” Journal of Economic Literature $56(2): 640-42$.

Rivera-Batiz, Luis, and Paul Romer. 1991. "Economic Integration and Endogenous Growth." The Quarterly Journal of Economics 106 (2): 531-55.

Randolph, Jan. 2001. G-Index: Globalization Measured. London: World Markets Research Centre.

Rodrik, Dani. 1998. "Who Needs Capital Account Convertibility?" In Should the IMF Pursue Capital Account Convertibility?, edited by Stanley Fischer, Richard Cooper, Rudiger Dornbusch, Peter Garber, Carlos Massad, Jacques Polak, Dani Rodrik, and Savak Tarapore, 55-65. Essays in International Finance 207. Princeton: Princeton University.

Rodrik, Dani, Arvind Subramanian, and Francesco Trebbi. 2004. "Institutions Rule: The Primacy of Institutions over Geography and Integration in Economic Development." Journal of Economic Growth 9 (2): 131-65.

Sachs, Jeffrey D., and Andrew Warner 1995. "Economic Reform and the Process of Global Integration." Brookings Papers on Economic Activity 26 (1): 1-118.

Sampson, Gary, and Stephen Woolcock. 2003. Regionalism, Multilateralism and Economic Integration: The Recent Experience. Tokyo: United Nations University Press.

Seshanna, Shubhasree, and Stephane Decornez. 2003. "Income Polarization and Inequality across Countries: An Empirical Study.” Journal of Policy Modeling 25 (4): 335-58.

Söderbaum Fredrik, and Timothy M. Shaw. 2003. Theories of New Regionalism. Basingstoke, UK: Palgrave Macmillan.

Srivastava, Muni S. 2002. Methods of Multivariate Statistics. Hoboken, NJ: Wiley-Interscience.

Tanzi, Vito. 1995. Taxation in an Integrating World. Washington, DC: Brookings Institution.

United Nations Development Programme. Human Development Index dataset. http://www.hrd.undp.org/. 1999. Human Development Report 1999: Globalization with a Human Face. New York: Oxford University Press. 
Vujakovic, Petra. 2009. "How to Measure Globalization? A New Globalization Index (NGI)." WIFO Working Paper No. 343.

Walz, Uwe. 1998. “Does an Enlargement of a Common Market Stimulate Growth and Convergence?” Journal of International Economics 45 (2): 297-321.

Woolcock, Stephen. 2006. "Introduction." In Trade and Investment Rule-making: The Role of Region and Bilateral Agreements, edited by Stephen Woolcock. Tokyo: United Nations University Press.

World Bank. DataBank. http://databank.worldbank.org/.

2002. Globalization, Growth and Poverty: Building an Inclusive World Economy. Washington DC: World Bank and Oxford University Press. 


\section{A New Index of Globalization \\ Measuring Impacts of Integration on Economic Growth and Income Inequality}

This study introduces a new composite index of globalization building on the separate contributions of intraregional and extraregional integration. Using the new index, the study also evaluates the possible effects of globalization on economic growth and income inequality. The results show that although globalization promotes economic growth, it may worsen income inequality. The positive effect of globalization on economic growth is strongest among high-income economies. The analysis also finds extraregional integration to be mainly responsible for the rise in income inequality that has accompanied globalization.

\section{About the Asian Development Bank}

$A D B$ is committed to achieving a prosperous, inclusive, resilient, and sustainable Asia and the Pacific, while sustaining its efforts to eradicate extreme poverty. Established in 1966, it is owned by 68 members -49 from the region. Its main instruments for helping its developing member countries are policy dialogue, loans, equity investments, guarantees, grants, and technical assistance. 